Portland State University

PDXScholar

Winter 3-28-2019

\title{
Arctic Security: the Race for the Arctic through the Prism of International Relations Theory
}

Michael Gregory Morgan Trujillo

Portland State University

Follow this and additional works at: https://pdxscholar.library.pdx.edu/open_access_etds

Part of the International Relations Commons

Let us know how access to this document benefits you.

\section{Recommended Citation}

Trujillo, Michael Gregory Morgan, "Arctic Security: the Race for the Arctic through the Prism of International Relations Theory" (2019). Dissertations and Theses. Paper 4823.

https://doi.org/10.15760/etd.6699

This Thesis is brought to you for free and open access. It has been accepted for inclusion in Dissertations and Theses by an authorized administrator of PDXScholar. Please contact us if we can make this document more accessible: pdxscholar@pdx.edu. 
Arctic Security:

The Race for the Arctic Through the Prism of International Relations Theory

by

Michael Gregory Morgan Trujillo

A thesis submitted in partial fulfillment of the requirements for the degree of

\author{
Master of Science \\ in \\ Political Science
}

\begin{abstract}
Thesis Committee:
Joshua Eastin, Chair

David Kinsella

Christopher Shortell
\end{abstract}

Portland State University

2019 
(C) 2019

Michael Gregory Morgan Trujillo 


\begin{abstract}
:
The purpose of the thesis is to examine future international relations in the Arctic as a theoretical exercise based on realism and liberalism. As the ice cap shrinks, and the region's environment changes, developing costs will decrease allowing for resourceextraction while new transit routes emerge. The opportunities to develop resources and ship via the Arctic are economic and strategically valuable, altering the geopolitics of the region. This thesis seeks to explore how resource development and new transit routes will affect regional politics through the lens of two theories. The two theoretical approaches will examine states and actors' interests and possible actions. Concluding, that realism will best describe the Arctic as states strive to be the regional hegemon by controlling transit routes and resources or defending the regional status quo, creating tension and a security competition between the U.S., China, and Russia. States will jockey for position within institutions before the ice cap disappears and transit routes emerge. These states seek to grow regional governance in their favor, providing support for a liberal framework, and possibly creating a structure strong enough to reduce tension before states strive to be the Arctic hegemon.
\end{abstract}




\section{Dedication}

To my wife, Ashly, for her continued support and love throughout college all

while being a great mom to Ethan and Ezra. Also, my parents for everything they have done for me. 


\section{Acknowledgements}

I am thankful to Dr. Joshua Eastin, Dr. David Kinsella and, Dr. Christopher Shortell for their feedback and time. 


\section{Table of Contents:}

$\begin{array}{ll}\text { Abstract } & \text { i }\end{array}$

Figures $\quad$ V

$\begin{array}{ll}\text { Ch. } 1 \text { Intro } & \text { P. } 1\end{array}$

$\begin{array}{ll}\text { Ch. } 2 \text { Literature Review } & \text { P. } 20\end{array}$

$\begin{array}{ll}\text { Ch. } 3 \text { Arctic Background and Governance } & \text { P. } 44\end{array}$

$\begin{array}{ll}\text { Ch. } 4 \text { Foreign Policy Analysis } & \text { P. } 62\end{array}$

$\begin{array}{ll}\text { Ch. } 5 \text { Three Theories of International Relations } & \text { P. } 70\end{array}$

$\begin{array}{ll}\text { Ch. } 6 \text { Conclusion } & \text { P. } 88\end{array}$

$\begin{array}{ll}\text { Works Cited } & \text { P. } 93\end{array}$ 


\section{Figures}

Figure 1 Map of the Bearing Sea Donut Hole (Baily 2011) P. 6

Figure 2 NOAA GFDL Climate Research Highlights Image Gallery (NOAA 2016) P. 7

$\begin{array}{lll}\text { Figure } 3 \text { Map of China's Polar Extension to Silk Road (Noi 2018) } & \text { P. } 28\end{array}$

Figure 4 Map of Russia’s Arctic build-up (Gramer 2017) 


\section{Chapter 1:}

\section{Intro:}

"We are entering the Age of the Arctic," after the region was thought to be inhospitable and undevelopable (Osherenko and Young 1989 p.3). States are jockeying for legal and political control over resource development and shipping routes. Militarization is starting to ensure security for future economic ventures and sovereignty claims (Osherenko and Young 1989).

During the Cold War, the Soviet Union and the United States believed that owning the Arctic allowed for control of the world, as the Arctic is the shortest route between Moscow and Washington. The current strategic geopolitical importance of the Arctic hasn't reached similar levels as the Cold War. However, with climate change and a shrinking ice cap, the Arctic's geopolitical importance is rising. An ice-free Arctic will open shorter shipping routes and allow for resource development.

It is estimated that the Arctic holds thirty percent of the world's remaining undeveloped natural gas, and thirteen percent of the world's remaining undeveloped oil. The two resources are estimated to be worth over 1 trillion dollars. It is believed that the Arctic holds more fossil fuels than Saudi Arabia (U.S. Navy 2014). Around eighty-four percent of the energy resources are located offshore (Gratz 2012). At the moment, there is no indication of conflict in the Arctic because development is expensive. However, conflict cannot be ruled out due to disputes between continental shelf claims, and the future impact transit routes and energy will have on the region. The frozen Arctic increases the costs for development when there are cheaper, easier to access oil and natural gas deposits. The transit routes are too risky or impossible to use. "Climate 
change may start a scramble for resources not seen since the 19th-century gold rush in California" (Lamy 2017 p. 80). This raises questions about resource and territorial claims whose legal framework exists in an ad hoc, rudimentary form as the ice the ice melts and new opportunities arise. (Lamy 2017).

Current levels of cooperation among states and international organizations keep tensions low despite different interests on Arctic transit routes and energy. States believe issues such as climate change and natural disasters are too broad and multifaceted for single states to solve. The circle contains eight states, and many nations with historical development. Multi-level agreements exist between governments and organizations. There are two defined but opposing discourses on Arctic geopolitics. One discourse is based on liberalism, focusing on peace and stability in the region through institutionalized international cooperation. The realist perspective argues there is a race for natural resources and economic interests that will produce regional conflicts (Heininen, Sergunin, and Yarovoy 2014).

This thesis seeks to examine the future of Arctic transit and resource development relations through realism, and liberalism as a theoretical exercise. The theories will examine how states might potentially act within the Arctic theater. I argue the realist theory will best describe the future of the Arctic since states will seek to protect their interests and expand their economy. However, states will use force when necessary. The region lacks binding institutions and law. States will use regional institutions to increase their power and legitimacy while expanding their economy and military. However, other forms of governance such as the North Atlantic Treaty Organization (NATO) and the European Union (EU) are censured for expansion towards Russia. A liberal framework 
has a chance to cause regional tension, but liberal theory can also explain regional stability since the 1980s. Future Arctic relations can either be: conflictual over resources and transit; stable under a new regional/global order; or competing institutions' use of international law and favorable forums to influence regional policy. This paper seeks to explore possible actions that will determine Arctic relations.

This thesis starts with the historical background of the region, and how climate change will bring new opportunities for energy development and transit. Diplomacy is used in the region to settle boundary disputes, but current problems and rising tensions between great powers will lead to clashes of interest. Next, the paper explains liberal and realist frameworks to describe Arctic relations based on regional governance and states' Arctic policy. Finally, I argue, realism will be the best theory to explain the region because states have proclaimed they will use force when necessary to defend their economic interests. States will clash when their interests diverge, leading to regional proxy and economic wars like the current ones in Syria and Ukraine.

Furthermore, Russia started militarizing the Arctic in 2008. Russia will continue until they return to Cold War levels in anticipation of protecting their sovereignty and developing resources. China also seeks new transit routes to expand the One Belt, One Road initiative through a Polar Silk Road. This leaves the U.S., the West, and NATO scrambling to avoid the Arctic turning into a Russian or Chinese sphere of influence.

\section{Background:}

Norway was the first state to claim Arctic waters with a Royal Decree in February 1812. In 1825, Great Britain and Russia signed a treaty demarcating their boundaries around the North Pole. Russia later sold their western boundary, Alaska, to the U.S. in 
1867. In 1878, the Canadian Parliament asked the British Parliament to transfer the North American Arctic to them. In the same year, the first Arctic organization formed with the International Polar Commission. The commission organized the first International Polar Year with eight governments participating (Schonfeldt 2017).

Two years later, Britain transferred all possessions in North America to Canada, Britain ceded all Arctic territory with the transfer. Britain also had a dispute with the U.S. over seals in the Bering Sea. The U.S. won the case after arbitration. Later, Britain and the U.S. signed the Hay-Herbert Treaty to settle the boundary between Alaska and Canada. Canada claimed sovereignty and started to patrol their northern archipelago after the treaty (Schonfeldt 2017).

In 1920, the Svalbard Treaty gave the fourteen signature parties full sovereignty over the islands and waters for industrial and mining enterprises. Currently, there are forty-five signature parties to the Svalbard Treaty. Two years later, the U.S.S.R. tried but failed to establish a transit route between the Atlantic and Pacific oceans. However, the Soviet Union established polar research stations. The Soviet government later demarcated its borders in 1926, claiming the Svalbard area of the Bering Sea, and parts of the North Pole (Heininen 2017). Before World War II, the second International Polar Year took place with forty governments participating.

The Arctic Ocean and the Norwegian Sea provided shipping routes to Murmansk to assist the Soviet Union as part of the U.S. Lend-Lease program. The U.S. also built the Thule Air Base in Greenland during World War II. After the war, Canada and the U.S. agreed to joint defense measures in the Arctic. Regional governance began with the 
creation of the Nordic Saami Council as a forum for Saami people across Finland, Norway, Sweden and the Soviet Union (Schonfeldt 2017).

The U.S.S.R. released a statute defining Soviet waters as any body of water that historically belonged to the Russian Federation in 1960. The U.S.S.R. offered the Northern Sea Route as an alternative route when the Suez Canal closed due to the ArabIsraeli War of 1967. This venture was unsuccessful. The United Nations Convention on the Law of the Sea (UNCLOS) conference started in 1973. American President Ronald Reagan announced the establishment of the U.S. exclusive economic zone (EEZ) without signing the convention in 1980 . However, socialist countries proclaimed the U.S. was trying to undermine UNCLOS. The Arctic came under traditional classical security geopolitics as states sought to control territory to serve as a defense buffer and develop resources during the Cold War. As the Soviet Union and the U.S. competed in an arms race, the Arctic transformed into a military flank and a battle for the sea-lanes of communication (SLOC) between Europe and America (Heininen 2017).

Reagan and Gorbachev met in December 1987 to support the development of regional cooperation based on Gorbachev's Arctic zone of peace speech. Later in 1990, the two states signed the Shevardnadze-Baker agreement, agreeing to resolve unregulated fishing in the Bering Sea Donut Hole. The Donut Hole is an international area between the coastal waters of the U.S. and Russia that had lucrative pollack fishing. 


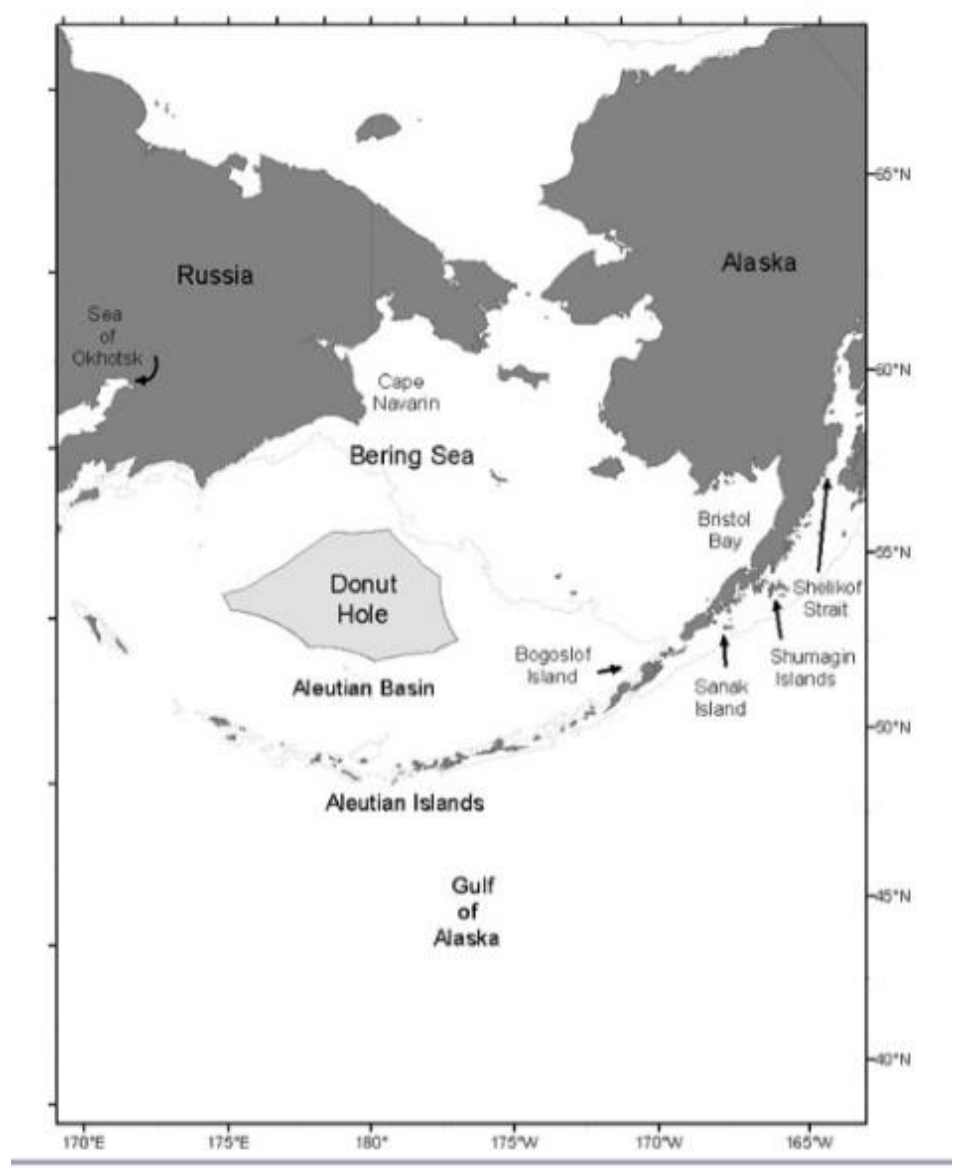

Figure 1 Map of the Bearing Sea Donut Hole found in (Bailey 2011)

Japan, Norway, and Russia established the International Northern Sea Route Program to study shipping lanes in 1993. The UN established the Commission on the Limits of the Continental Shelf (CLCS), allowing states to extend their EEZ to 350 nautical miles or 150 nautical miles past the UNCLOS EEZ limit in 1997.

Four years later, Russia made a submission to CLCS, arguing the Lomonosov and the Mendeleev Ridges as extensions of the Siberian Shelf of the Eurasia continent. To further prove their claim, scientists traveled the ocean floor to take soil samples from the Mir-1 and Mir-2 bathyscaphes while planting a Russian flag at the North Pole. The flag 
created an outrage. Canadian Foreign Minister, Peter MacKay stated, “This isn't the 15th century. You can't go around the world and just plant flags and say, 'We're claiming this territory" (Alexandrov 2009). However, Danish and Canadian scientists argue the Lomonosov Ridge is an elevator ridge attached to the older Greenland and North American plates (Powell 2010). Until recently, Arctic resources were too difficult to develop; however, a melting ice cap and future ice-free transit routes heat up the Arctic's geopolitics.

Historically, Arctic development was too costly and risky to undertake. The cost and risks left many states and companies uninterested in Arctic expansion. However, the Arctic ice cap is at the lowest ever since satellites started keeping records (Carrington 2017) and estimated to shrink more.

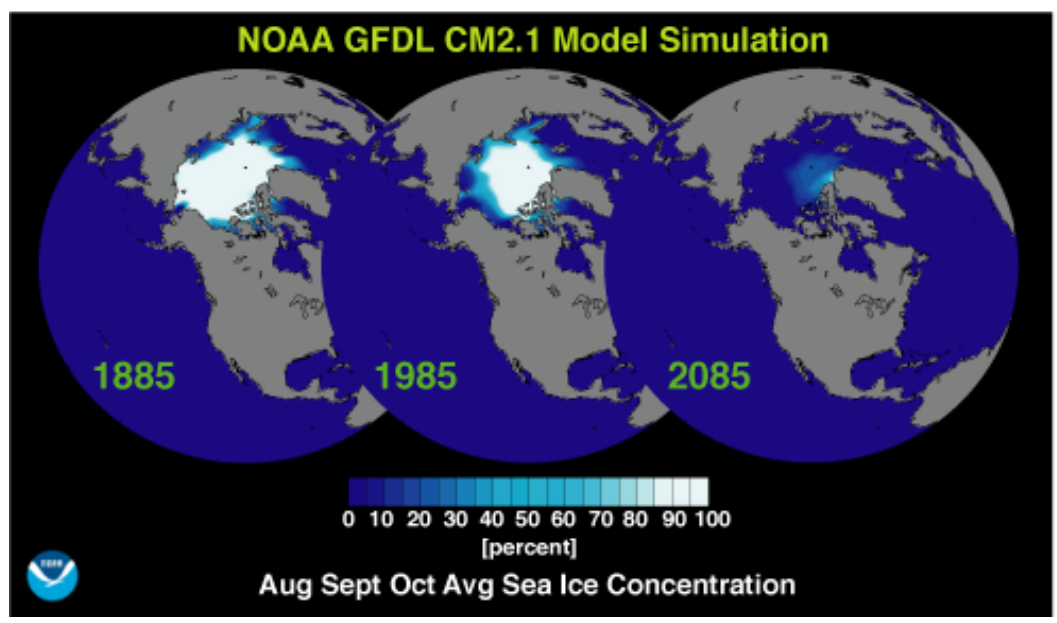

Figure 2 NOAA GFDL Climate Research Highlights Image Gallery from (NOAA 2016)

Arctic resources and transit routes are becoming a safer investment to develop due to the thinning ice cap reducing costs and risk. States have strategic interests in either developing energy or securing transit routes. Russia, the U.S., and Canada see the Arctic 
as a natural barrier, and the opening of the Arctic creates security problems. Furthermore, Russia and China need oil and trade to increase their economy and military. Russia's expansion to China and Asia has the potential to end Russia's dependency on Europe's markets. However, Europe imports energy from unstable regions and wants a steady, secure independent source (Krickovic 2015). Finally, Canada and the U.S. seek to develop national resources to become energy independent. International relations are a bargaining game for the distribution and redistribution of resources (Legro and Moravcsik 1999). "Economic and technological competition is as often as keen as military competition" (Waltz 1993 p. 57).

\section{Conflict previously mitigated:}

States settled border disputes diplomatically, Canada and Denmark agreed on the Hans Island delimitation in 1973, later ratified by the UN. Iceland and Norway signed an agreement in 1981 to demarcate the continental shelf between Iceland and Jan Mayen. Iceland also reached an agreement with Norway and Denmark in 2006 for Iceland's claim of 200 miles in the Norwegian Sea.

Russia and Norway used UNCLOS to set the maritime limit for the Barents Sea in 2010. "It has removed a potential source of conflict between Norway and Russia and is an excellent example of current cooperative attitudes in the High North" (Luszcak 2017 p. 42). The Barents Sea has fisheries and natural resources, including a vast amount of energy resources. In 2006, Russia, Norway, Iceland, and Denmark agreed to a modus vivendi for claiming continental shelves beyond 200 nautical miles. In late 2010, Norway and Russia signed a new treaty dividing the disputed area into two halves, thus defining 
the boundaries for energy resource development. It appears both Russia and Norway seek to mitigate their dispute through diplomatic means according to international law.

"Arctic States have on several occasions declared their commitment to resolve and, in some cases, have worked towards resolving possible conflicts of interests according to the principles of international law" (Schönfeldt 2017 p. 59). Small powers in the Arctic have a history of cooperation, and the region also produced cooperation between a great power and smaller powers. However, great power cooperation with other great powers is limited in the region. Only the future can tell whether international organizations are strong enough to keep states committed to agreements and thus, being able to defuse all the possible points of tension in the Arctic.

\section{Current problems:}

The Northwest Passage has a minor conflict over the designation. The U.S. regards the passage as an international strait, while Canada believes it's their internal water. If the passage is designated as an international strait, then no states need to ask for permission to use it. If it is designated as internal Canadian waters, then foreign ships must ask Canada for permission to pass. It's unlikely the U.S. will grant Canada's claim, as it would set a precedent for Russia to claim the Northern Sea Route, China to claim the South China Seas, and for Iran to claim the Strait of Hormuz as internal waters (Huebert 2009). However, as Canada and the U.S. regard each other as strategic partners, the U.S. probably won't publicly challenge Canada's designation of the Northwest Passage.

The disputed Bering Sea has three potential issues. First, the Bering Sea is an important area for Russian and American fishing industries. In 2006, the area was worth $\$ 600$ billion for the Russians, and around \$1 billion for the U.S. Second, the effect 
hydrocarbons and other natural resources play in the Bering Sea and the adjacent East Siberian and Chukchi Seas where maritime and continental shelves are not agreed upon. Finally, the Bering Sea is an important junction between Asia, Europe, and North America with trade and security concerns (Kaczynski 2007).

When Russia sold Alaska to the U.S. in 1867, the treaty outlined maritime boundaries but not EEZs or continental shelves. The two states exchanged diplomatic notes in 1977 to demarcate the border. However, different interpretations of the treaty led to an overlap of about 15,000 square nautical miles. Both states signed the BakerShevardnadze Agreement to split the difference between the U.S. claim on a geodetic line, and a rhomb line used by the Soviets in 1990 (Kaczynski 2007). However, the new Russian government claimed the agreement invalid since the Soviet Foreign Minister Eduard Shevardnadze did not represent Russia's interests. Russia failed to ratify the agreement since Shevardnadze ceded the Neversink fields, the Aleut hydrocarbon fields, as well as fishing areas and quotas for concessions (Heininen, Sergunin, and Yarovoy 2014). As of today, there is no formal agreement on the demarcation in the Bering Sea, but the U.S. enforces the 1990 treaty (Kaczynski 2007). The U.S. Senate quickly ratified the deal to lease off energy resource claims (Heininen, Sergunin, and Yarovoy 2014). Moscow formally observes the agreement, thus providing evidence of opinio juris practice. The Bering Sea will remain conflict-free as resources and transit are currently too difficult and costly.

Norway and Russia have a fishing dispute around Spitsbergen. Norway claims a 200-mile EEZ around Spitsbergen and regards Russian fishing in the area as poaching. The Norwegian Navy arrested Russian fisherman leading to regular patrols by Russia's 
Northern Fleet. (Heininen, Sergunin and Yarovoy 2014). However, Norway’s Statoil, France's Total, and Russia's Gazprom signed a joint agreement to form the Shtokman Development AG Company to develop the Shtokman field. Statoil and Russia's Rosneft also formed a consortium for joint development in the Barents Sea and the Sea of Okhotsk. While there is a fishing dispute, the need for energy fostered cooperation and stability to develop resources. It appears Spitsbergen will remain conflict free with economic development and past Norwegian and Russian diplomacy.

Denmark and Russia have conflicting claims over the Lomonosov Ridge. Russia made the first UNCLCS submission in 2001 but rejected for insufficient evidence. Danish scientists claim the Lomonosov Ridge connects to the Greenland and North American plate. As a smaller power, Denmark doesn't want to challenge Russia by force preferring to work through institutions and agreements (Denmark 2016).

Canada has territorial disputes over the Lomonosov Ridge, the Hans Island, the borderline of the Lincoln Sea, and the border of the Beaufort Sea with Denmark. Both Canada and Denmark submitted a request to UNCLOS in 2013, claiming part of the Lomonosov Ridge between the North Pole and Ellesmere Island. It seems this conflict will remain out of the public's eye without an increase in tension between the two states since both are NATO members.

Tensions in the Arctic will rise if states can't solve territorial and resource disputes diplomatically. Currently, states are not emphasizing their regional conflicts while using Arctic institutions and international law to mitigate conflict. However, if UNCLCS rules the Lomonosov Ridge as Danish, Canadian or American, this could cause tension as Russia believes they legally have right to the ridge and its resources. 


\section{Possible points of tension:}

The unresolved territorial claims in the Barents Sea, the Bering Strait, and the Beaufort Sea will remain possible points of tension until resolved. States are increasing their militaries to claim and signal sovereignty in the Arctic. To signal sovereignty, Arctic states are increasing their surveillance of territorial waters and EEZs, search and rescue operations, and environmental protection.

The U.S.S.R. first regulated transportation through the Northern Sea Routes and Russia still tries to regulate the conditions of passage since the route is within their EEZ. However, the U.S. rejects the regulations, claiming the route as an international strait and argues Russia is acting beyond its territorial waters. Russia attempts to institutionalize these regulations by investing in northern ports and regional patrols to establish jurisdiction. However, before Western sanctions, Russian and American companies, Rosneft, and ExxonMobil had deals to develop the Kara Sea for energy. Both Russia and the U.S. seek to develop resources in the region.

States that ratify UNCLOS must submit claims to the CLCS within ten years of acceding to the convention. All states assured their commitment to abide by the Convention despite the U.S. not ratifying UNCLOS. It is "estimated that about 88 percent of the seabed of the Arctic Ocean would be under the control of the Arctic littoral states if the Commission on the Limits of the Continental Shelf were to approve all the existing or expected claims to the Arctic Ocean continental shelf" (Heininen 2017 p. 46). However, non-Arctic states may also stake a claim to the Arctic without acknowledging UNCLOS or the International Seabed Authority. If continental shelf claims are granted, it would limit China's access to shipping routes and resource development. Both Canada and 
Russia favor classifying the Northern Sea Route and the Northwest Passage as internal waters for economic reasons (Heininen, Sergunin, and Yarovoy 2014). However, the U.S. opposes them being designated internal waters. Continental shelf claims that don't rule in favor of a state could lead to disputes and possible military posturing. The current military build-up in the region is not for a large-scale war, rather to protect economic interests and territorial sovereignty.

Danish Foreign Minister Per Stig Møller thought the "Arctic Five" should be able to solve the region's problems in 2007. The five included the U.S., Russia, Canada, Denmark, and Norway, all with Arctic coastal waters. "It remains unlikely that any of the five Arctic littoral states will risk a large-scale, intrastate military conflict. There remains a possibility that tensions could increase due to misperceptions, and rhetoric, as well as the unforeseen dynamics of economic interests in the region" (U.S. Navy 2014 p. 14). Iceland complained about the Arctic Five and argued any decision without Reykjavik, Helsinki, Stockholm, and indigenous groups is not valid. The complaints paid off since the Arctic Five did not institutionalize any policy. Subsequently, the Arctic Council has been the main institute for regional policy (Guschin 2015).

Chinese companies Sinosteel and China Communications Construction Corp. formed a joint mining company with London Mining to produce magnetite in Greenland. Kvanefjeld Mine is estimated to have one of the largest rare earth elements deposits and a copious amount of uranium. Chinese control over Kvanefjeld is a strategic asset allowing China to influence global prices as China already controls the majority of rare earth element development (Alexeeva and Lasserre 2012/3). China also invests in a ferrosilicium plant in Iceland, ferrosilicium is essential to the mass production of solar 
panels. This increases China's dominance over the emerging solar energy sector. Norway also exports iron ore, methane, and oil to China (Alexeeva and Lasserre 2012/3). Finally, when Arctic sea lines melt, Chinese ships would be able to bypass the Strait of Malacca, the Strait of Hormuz, and the Suez Canal, each with heavy traffic and security concerns, while decreasing shipping time.

"China attributes significant importance to its energy and economic partnership with Russia in the Arctic zone" (Alexeeva and Lasserre 2012/3 p.66). Moscow believes China is an Arctic investment partner (Blank 2012). Putin has promoted the development of Sino-Russian ties and cooperation in the Arctic (Alexeeva and Lasserre 2012/3). Putin's office released a statement "the unprecedented high level of relations between Russia and China achieved recently due to the personal efforts of Xi Jinping," (President of Russia 2018). "Currently, the China-Russia comprehensive strategic cooperative partnership is at the best level in history, which sets an example for building a new type of international relations," stated Xi in March (Xinhua 2018). China seeks to keep promoting Sino-Russia relations (Xinhua 2018). However, both Russia and China lack the knowledge and equipment for Arctic resource extraction. China wants to increase exploration of resources since they are a large energy consumer (Alexeeva and Lasserre 2012/3). China's private CEFC Energy bought a stake in Russian state-owned Rosneft early in 2017 (Mazneva, Bierman and Blas 2017). CNPC, China National Petroleum Corporation, a state-owned enterprise, bought a stake in Rosneft in 2013 (Rosneft Information Division 2017). Russia is now the top exporter of oil to China and plans to supply natural gas to China by 2019 (Aizhu, Mason, and Li 2018 and Cheong 2018). CEFC and Rosneft also have plans for joint development projects (Mazneva, Bierman 
and Blas 2017). This Chinese-Russian relationship benefits both sides as China is able to ensure energy security while Russia can increase tax revenue to build their economy. However, Putin and Xi are described as "a marriage of convenience at best" with the prospect of devolving into an Arctic rivalry when Chinese Silk Road and Russian Northern Sea Route interests diverge (O’Connor 2018). Past Sino-Russian relations have been rocky which included deaths in a border dispute in 1969. Russians in Russia's Far East worry about growing Chinese influence and migration as a way for Beijing to annex lost territory. The Chinese believe the Aigun Treaty between the Qing Dynasty and the Russia Empire was signed when China was weak, leading to an unfair agreement still imposed on them (Tselichtechev 2017).

Northern Eagle was an example of military cooperation but included two superpowers, the U.S. and Russia. Between 2004 and 2014, the U.S., Russia, and Norway conducted military exercises in the Barents Sea and the Northern Sea Route (Luszcak 2017). However, the biennial exercises were suspended in 2014.

"Although the Department of Defense finds value in the military-tomilitary relationship with the Russian Federation we have developed over the past few years to increase transparency, build understanding, and reduce the risk of military miscalculation we have, in light of recent events in Ukraine, put on hold all military-to-military engagements between the United States and Russia," stated chief Pentagon spokesman, Rear Adm. John Kirby (LaGrone and Majumdar 2014).

NATO and the U.S. ordered Russia to leave Ukraine, as the Ukrainian conflict and other breaches in international law by Russia pose a challenge to Euro-Atlantic and 
Arctic security (NATO 2014). "The underlying problem seems to be a persisting lack of certainty about other actors' peaceful intentions" (Atland 2014 p. 146). States signaled that they seek peace in the Arctic, but Russia has increased their military capacity in the region. Currently, the U.S. has other, more pressing security challenges, but that does not exclude the possibility of conflict in the Arctic due to Russian aggression. Given this context, Russia and China will cooperate to balance against the U.S. because they will increase their chance of survival (Waltz 1979) by creating spheres of influence to serve their economic needs. The smaller powers in the region will bandwagon with either the U.S. under NATO or Russia but won't make enough of a difference to shift the balance of power to either side.

Russia and the U.S. use their nuclear assets in the Arctic for sovereignty claims and defense. An ice-free Arctic would allow the U.S. to escape from their lack of icebreakers as the U.S. only has two icebreakers compared to Russia's forty-one icebreakers. The melted Arctic would allow the normal U.S. navy to operate in the region and ensure the freedom of navigation.

Also, the U.S. is shifting their ballistic missile defense to sea-based components. This activity might trigger manifestations of the United States projecting naval power in a region that Russia claims, such actions carry the risk of misunderstanding of intentions possibly sparking a security dilemma. Russia had a strong reaction to the U.S./NATO proposed interceptor missiles as part of the Ground-Based Midcourse Defense system in the Czech Republic and Poland (Luszczak 2017). Putin suggested Russia would not comply with the 1990 Conventional Forces in Europe Treaty and threatened to suspend all ties with NATO if the U.S. built the new system. In 2015, Mikhail Vanin, Russian 
ambassador to Denmark, wrote an editorial to Jyllands-Posten, a Danish paper, stating that Denmark's ships would be targets of Russian missiles if they joined NATO's missile defense system (Herszenhorn 2015). The opening of Arctic seas to western ships might make Putin nervous as he seeks natural barriers to protect against any invasion, possibly giving Putin an incentive to attack first.

"As Russia re-emerges from decades of economic stagnation and considers its national future, the Arctic is, once again, a central focus. The Russian vision of the Arctic is as a source of material strength and national power" (Emmerson 2010 p. 69). As sovereignty claims and aggressive actions increase so will the tension between actors unless Arctic governance keeps the region stable. Realism will become the best framework to describe Arctic relations when development costs become cheaper and transit is safer. Economic interests will then trump regional cooperation. Currently, it seems like liberalism would best describe Arctic international relations. This is because regional governance based on mutual interests increased significantly since the end of the Cold War. However, the stakes were low since development was nearly impossible and extremely costly. Second, some states don't want Arctic governance to focus on security issues because they do not want to limit their sovereignty in the region and Russia worries about NATO and the EU expanding to their border. Third, the U.S. and Russia will most likely not be able to solve the "easy disputes" of Syria, Ukraine, and border issues. Forth, the U.S. is unlikely to end sanctions on Russia, further impeding any Arctic cooperation between the two states. Finally, the Arctic has no framework or lacks a strong enough collective security to stop a large power from partaking in unilateral action when its interests are challenged. These reasons are why a liberal framework will be 
unable to explain the region. "The tectonic shifts that are happening are the rise of a powerful China... and the resurgence of a weak, but very dangerous, and well-armed Russia, so the return of a period of great power competition is happening" (Flournoy 2017). However, if the U.S. cedes it global hegemonic status and doesn't secure its interests, Russia and China would create their own regional order based on the Silk Road economic bloc, allowing the Arctic to remain stable.

Russia and China seek to be the regional hegemon or create a sphere of influence since projecting force across the world is costly and hard. Under the One Belt, One Road initiative, China seeks to establish a trade block with sixty states, hoping to shift the global economy to its favor, altering the global balance of power. China seeks safe polar routes protected by Russian forces. Once states have an Arctic regional sphere that suits them, states will protect their interests by any means necessary. America can either allow the new Polar Silk Road and a shift in the balance of power or seek to stymie the progress through sanctions/force. As China shifts to new markets and an economic bloc centered on them, U.S. dependence on Chinese goods could be a weakness to exploit by Beijing. "Rivals like China and Russia that challenge our interests, our economy, and our values. In confronting these dangers, we know that weakness is the surest path to conflict, and unmatched power is the surest means of our defense" (White House 2018). There will always be security competition, and it will be intense at times when states seek either regional or global hegemony.

The next chapter explains how liberalist and realist theories can be a framework to explain Arctic relations. In Chapter Three, Arctic governance and state's Arctic policies will be analyzed to predict potential actions in the region. Chapter Four is a 
foreign policy analysis of the region and how states' policies will influence their strategies. In Chapter Five, liberal and realist frameworks will explain possible outcomes based on states' strategies and policies. Finally, Chapter Six is the conclusion, explaining why realism will be the best framework for describing Arctic international relations. Finally, I argue, realism will be the best framework to explain the region due to states willingness to use force when necessary when their interests diverge. However, the U.S. will cede regional power to Russia and China, allowing them to form a new economic bloc. 


\section{Chapter 2:}

\section{Literature Review: Two theories of International Relations:}

"No single approach can capture all the complexity of contemporary world politics. Therefore, we are better off with a diverse array of competing ideas rather than a single theoretical orthodoxy" (Walt 1998 p. 29). Arctic institutions and organizations expanded in scope, size, and number, providing evidence for a liberal framework. However, regional powers stated they will use force to protect their interests when diplomacy doesn't work, best explained through realism. All theories are useful in the intellectual toolbox. Each theory has its strengths but also has its weakness. However, it appears Arctic governance won't be able to deescalate rising tensions between regional powers, leading to a clash of interests, best explained through realism.

Realists argue institutions reflect the global power balance, and changes in the balance generate changes in institutions (Walt 1998). Russia and China want to grow Arctic governance to favor their economic development and change the global balance of power. Regional governance in Russia's favor will allow them to design their sphere of influence. China seeks to grow its influence in Arctic governance to shape transit policy for their Polar Silk Road, potentially allowing the One Belt, One Road to span all of Eurasia. However, the U.S. is reluctant to increase Arctic governance or spend money in the region as the U.S. has other priorities around the world. American leaders are starting to focus on great power competition (Flournoy 2017 and Coats 2018), ensuring a future Arctic pivot, as the region is crucial to both Russian and Chinese interests. Russia and the U.S. would use force when necessary in the region to protect their interests, which center 
on energy development and transit routes. The U.S. seeks to protect the status quo while Russia and China wish to shift the balance of power away from the United States. International relations are bargaining over the distribution of resources or an incessant competition for resources. There is the possibility of conflict between states over any valued good, ranging from economic interests/goods, territory, and political/economic ideology (Legro and Moravcsik 1999). It appears state interests for energy and trade routes will cause conflict in the region. The literature review focuses on realist and liberal theoretical approaches of international relations. The theories will frame the argument and form conclusions based on each state's Arctic policy and actions.

\section{Liberalism:}

In the liberal perspective, the world has order and a hierarchy structured by institutions' laws and rules despite global anarchy. The fundamental premise of liberalism is the relation between states and international society because international society influences and shapes state behavior through social purposes (Moravcsik 1997). States still compete but cooperate on economic and other issues under the auspices of institutions. Institutions create common rules, principles, and standards of behavior that constrain state action but foster long-term cooperation through mutual benefits. Arctic organizations were formed to focus on common interests based on search and rescue, environmental protection, economic development, and indigenous rights. The Arctic politically is characterized by years of cooperation, the absence of war, and adherence to the law creating a stable political order (Wegge 2011). By strengthening the legal Arctic framework, the region can attract international investment and development (Ebinger and Zambetakis 2009). 
Power is defined by bargaining and negotiation and a state's willingness to spend resources or make concessions to fulfill their preferences. Institutions reduce transaction costs to increase information being shared and mitigate the fear of defection. However, Russia is striving for favorable Arctic governance to increase their regional influence. On the other hand, the U.S. prefers regional diplomacy through unilateral, bilateral or multilateral negotiations depending on what suits their interests. America is against increasing international organizations that might impede U.S. sovereignty or curtail any action in the region. "It is the position of the United States that the Arctic Council should remain a high-level forum devoted to issues within its current mandate and not be transformed into a formal international organization" (White House 2009 p.4).

Since parties are not likely to increase the Arctic Council or sign a regional treaty, Young argues for the development of a governance structure in a sense of linked agreements that address specific topics but builds up a comprehensive regional structure (Young 2011). Past search and rescue, pollution, and climate agreements can be the foundation for the regional structure Young proposed. The U.S. and Russia have been willing to enter these types of deals in the past, even though they are reluctant to cede sovereignty to regional organizations. The prospect of this type of diplomacy can be a means to reduce tension and improve cooperation (Exner-Pirot 2012). The Arctic should not expect a regional governance structure to be built among linked agreements. Young makes a case for growing regional governance, but these agreements are better solved through multilateral arrangements rather than states trying to mitigate pollution or climate change by themselves. When states have diverging interests in security or economic 
issues, a linked agreement won't be formed because states don't share mutual interests. This refutes Young for an all-encompassing regional governance structure.

Hegemonic stability is when one state is so dominant that it can create and uphold a military and economic order with strong regimes that reflect the great power's interests, with Pax Britannica and Pax Americana as examples. The U.S. should not be considered the Arctic hegemon since the Arctic Council and UNCLOS are not American priorities (Wegge 2011). Stokke argues most Arctic institutions were established in the late 1980s to improve relations between the West and Russia to reduce tension in the area (Stokke 2012). However, Russia is seeking the Arctic hegemony to turn the region into a resource base. This would allow Russia to create a stable system based on international law that benefits their economy. If the regional order, international law, and military balance are in Russia's favor, Russia will advocate for a stable region because it's more cost-effective to achieve their goals than through military force.

Axelrod and Keohane argue there are three dimensions of international relations: mutuality of interest, the future, and the number of actors (Axelrod and Keohane 1985). If states have similar interests the likelihood of cooperation goes up. Alternatively, the greater the level of conflict between actors, the less likely they are to cooperate (Axelrod and Keohane 1985). States involved in Arctic governance have mutual interests in economic development and environmental protection, which is why cooperation is high in the Arctic, even though Russia and the U.S. have different interests in security. Moscow and China are both open to cooperation and investment opportunities in the region. Doing so, the two states seek diplomatic, and economic stability via regional governance structures (Konyshev and Sergunin 2014). 
Keohane and Martin expect states to form institutions to normalize relations when states benefit from cooperation. "Institutions can provide information, reduce transaction costs, make commitments more credible, establish focal points for coordination, and in general facilitate the operation of reciprocity." Institutions define the range of behavior states and actors can take to preserve the cooperative order by setting standards and rules. As a result, institutions promote and deepen ties between states to develop mechanisms of cooperation (Kupchan and Kupchan 1991). Interactions between states create issuelinkages fostering interdependence. The more states are connected, the more a state hurts itself when cheating (Lipson 1984). Keohane and Nye argue complex interdependence is reciprocal effects among actors when there is no hierarchy among policies, the presence of multiple channels of contact, and the irrelevance of military (Keohane and Nye 2012). Byers believes the Arctic has become an example of complex interdependence since the region doesn't focus on just one or a few topics; the multiple channels of contact between scientists, organizations and bureaucrats; and the reduced tension since the end of the Cold War (Byers 2017). Byers is partially wrong because while there is some complex interdependence, states had little interest in asserting their unilateral goals in the region due to development cost and risk. States and scientists are cooperating, but Russia and America have cut each other off in the security realm. If Northern Eagle continued, Russia joined NATO in the 1990s and other forms of military cooperation were taking place in the region, Byers argument for Arctic complex interdependence would be stronger.

Keohane and Martin argue cooperation and institutions make a difference in global power realities and influence international relations (Keohane and Martin 1995 p. 
42). States waging war harm their own interests in the complex interdependence of the region (Byers 2017). Both intergovernmental and interregional cooperation in Arctic organizations led to high stability in the region through regional standards (Heininen 2017). Currently, the Arctic is governed by eight highly developed states that cooperate more than in any other time in history.

Institutions matter when states are concerned about absolute gains because institutes administer agreements that benefit all parties (Keohane and Martin 1995). International agreements like UNCLOS and organizations such as UNCLCS and the Arctic Council seek to mitigate conflict to create stability to ensure states have a gain (Wang 2012). Absolute gains are important under liberalism, while relative gains matter for a realist. Relative gains compare what state A gained compared to state B, so each state seeking relative gains enters agreements in which they will have the largest gain. However, for absolute gains, institutions help mitigate fears of unequal gains through the exchange of information thus allowing each state to evenly gain (Keohane and Martin 1995).

International relations are best explained by states' fear of cheating and being taken advantage of or state A cooperating and state B defecting. The cost of resource development is high and transit routes can't be accessed, so there is not yet a reason for states to defect from international organizations. However, cheating and defection are discouraged because it raises the cost of future gains through cooperation. Though, the U.S. imposed sanctions on Russia, reducing cooperation between the two states, giving Russia an incentive to cheat since it won't hurt any future gains from cooperation. If the U.S. doesn't remove sanctions on Russia, this will limit regional cooperation. 
Abbott and Snidal argue "that international actors choose softer forms of legalized governance when those forms offer superior institutional solutions" (Abbott and Snidal 2000 p. 421). Hard law reduces transaction costs, strengthens the agreement's reputation, expands the institution's political strategies, and resolves issues with incomplete contracting. However, hard law also entails costs, and hard law limits states' behavior and their sovereignty. Abbott and Snidal believe states often choose softer forms of legalization to hard law because it has fewer restrictions. States, though, will seek hard law when it favors or is advantageous for them. Arctic organizations lack hard law because the U.S. does not want to cede sovereignty or limit future behavior because it is tied to a binding treaty. Flake argues a mitigating factor in the Arctic is the "abundance of very resolvable disputes" between the West and Russia (Flake 2017 p. 18), however, there is little progress to resolve those disputes. The regional governance structures and past agreements eliminated most sources of major conflict. However, maritime jurisdiction is still controversial. Russia believes international law favors their national interests, and cooperation can best secure that goal (Flake 2017). "This brings the Russian behavior (at least regionally, not globally) closer to the soft power model" (Konyshev and Sergunin 2014 p. 134). If the U.S. and Russia can resolve disputes such as Ukraine, Syria, and border conflicts between Russia and other western states (Flake 2017) this will greatly reduce support for realism as an explanatory framework for Arctic relations.

Before the Arctic becomes a battlefield for economic gains, regional organizations need to build on maritime regulation, environmental protection, and military limits to increase regional complex interdependence. The Arctic established soft 
law setting the norms and regulating behavior; however, the Arctic has two binding treaties. Regional, smaller power states are committed to using diplomacy to solve conflicts, which can be used to keep the Arctic stable and cooperative.

Arctic governance will continue to grow providing evidence for liberalism. Actors within the Arctic are interdependent via various organizations and institutions. Regional actors seek a stable Arctic where issue linkages are created via mutual economic and environmental interests. As low-level policy, such as policy focused on human welfare, indigenous rights, economic development and environmental protection becomes institutionalized through norms, issue linkages will spread to high-level policy such as security and sovereignty issues, which focus on the survival of the state, incentivizing cooperation.

\section{Realism:}

In the realist perspective, the world order rests on the distribution of power, which can create stability as well as war. When states struggle for power, they tend to go to war. The Arctic has two regional powers and abundant resources while an emerging power seeking to expand its global reach "makes it almost certain that the Arctic will not conform to the attributes of an integrated region in the foreseeable future" (Mottola 1988 p. 6).

The system is anarchic because the international system lacks authority and a mechanism to act as an arbitrator for states. Realists argue interstate behavior is uncooperative, distrustful, uncertain, and tense due to anarchy. States must protect their own interests to ensure survival. Dmitri Medvedev, the former Russian president, stated Russia seeks to turn the Arctic into their resource base and a sphere of influence. China 
also seeks to secure transits routes to consolidate a sphere of influence in Eurasia under their One Belt, One Road initiative while other middle powers seek to develop resources in the region.

\section{China's polar extension to Silk Road}

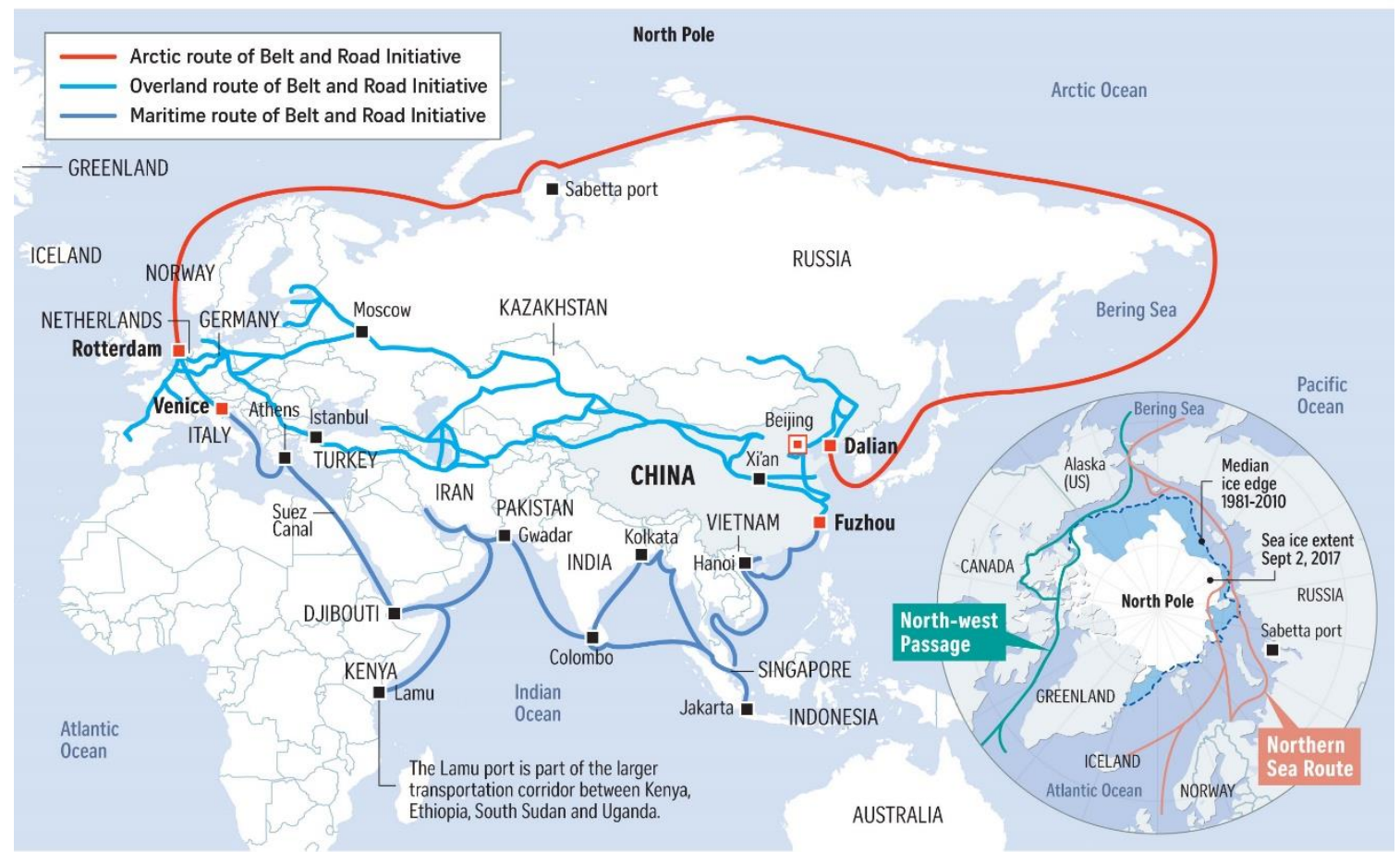

NOTE: September is the end of summer in the North Pole when the frozen lid of sea ice tends to shrink to its smallest. Unlike the Antarctica, there is no land under the frozen Arctic ice. Sources: CHINA'S NATIONAL DEVELOPMENT AND REFORM COMMISSION, THE ARCTIC INSTITUTE, NATIONAL SNOW AND ICE DATA CENTRE, REUTERS STRAITS TIMES GRAPHICS

Figure 3 Map of China's Polar Extension to Silk Road (Noi 2018)

China's Arctic strategy is the Polar Silk Road that would link Europe with China via the Arctic (Johnson and Standish 2018). "After the Northwest Passage is opened up it will become a new axial sea route between the Atlantic and Pacific... whoever controls the Arctic sea route will control the world economy and a new internationally strategic corridor" (Wright 2011 p. 1). However, the U.S. seeks to maintain a favorable balance of power in the Arctic and around the globe (DOD 2018), which might clash with other powers' interests. Sharp argues that Arctic security should consider CLCS and whether it 
is a security enabler by providing a framework for EEZ claims or a source of security stress due to its narrow mandate that doesn't consider the regional geopolitics (Sharp 2011). If UNCLOS' Lomonosov Ridge ruling is in favor of Denmark, this could cause Russia to take military action or disregard international law since they ensured their interests through law.

A realist strives to be the hegemon or the only great power in the system, thus controlling the system and the actors (Mearsheimer 2014). States must determine whether other states are revisionist or fine with the status quo. America as the current sole superpower is having its influence challenged across the globe, and the Arctic isn't excluded from rising tensions. Both Russia and China are revisionist states seeking to establish spheres of influence, one an Arctic sphere and the other a Eurasia sphere to become regional hegemons. The lack of institutional framework and the shift away from unipolarity is unlikely to keep the region stable (Murray 2012).

According to a realist, states fear each other and always anticipate danger. Fear is a motivator for a state's foreign policy since states are aware of the consequences of being a victim of an aggressor. States must be prepared to defend or live at the mercy of other states since no supreme authority will stop an aggressor. However, the political system in which they interact will place structural constraints on their actions (Waltz 1979). The Arctic transit routes not only serve as an economic interest but are fundamental to a state's naval strategy (Gratz 2012). "In facing this real and quite unpredictable scrabble and battle for the Arctic and the probability of some countries dividing up the Arctic melon with the aid of geographical advantage and military might, 
if peaceful means cannot produce the anticipated effects, war becomes the only method for resolving the issue" (Wright 2011 p. 6).

States are rarely content with the current balance of power unless they are the hegemon, so states have a constant incentive to shift the distribution of power to favor them. "The central challenge to U.S. prosperity and security is the reemergence of longterm strategic competition by... revisionist powers" (DOD 2018 p. 2). The great power in the system will defend the status quo, while other states try to undermine the distribution of power. Sometimes, the costs and risks of changing the distribution of power are too high, forcing states to wait for a more favorable situation. The U.S. can either willingly cede the regional hegemon and allow a new regional order or the U.S. can try to keep their global hegemon. If the U.S. remains absent from the region, a divorce from the marriage of convenience might take place as both Russia and China will be competing against each other to establish their own sphere of influence. Sino-Russia relations will tense up again.

In the system of international politics, states must be aware of their power in relation to other states in the system to help ensure their state survives. Russia and China, led by authoritative leadership, seek to maximize their power by creating a sphere of influence, leading to competitive situations with the U.S. However, it does not appear that either Russia nor China will seek to fully dominate the U.S. since a total war with nuclear weapons might lead to the downfall of a state, making survival impossible. Mearsheimer believes it's the structure of the international system that forces states to seek power. All great powers have the same incentive - survival. The best deterrence against another state attacking is to be powerful enough to protect the 
homeland. "Great powers are trapped in an iron cage where they have little choice to compete with each other for power if they hope to survive" (Mearsheimer 2013, p. 72). Russia has little choice but to develop the Arctic to jumpstart their stagnant economy to stop Western expansion into former Soviet territories and avoid domestic strife. China seeks an economic network to rival American centered trade deals while the U.S. hopes to remain the global hegemon.

The divide between neo-realists stems from the question: how much power is enough? The offense/defense balance is argued by Robert Jervis, Jack Snyder, and Stephen Van Evera that military power can be categorized as either favoring offensive/aggressive states or defensive/status quo states. They argue that if defense has an advantage over offense, conquest is difficult. States then have little reason to use force. They focus on protecting their powers and expanding their power through other means. States have incentives to use force to gain power when offense has the advantage. This is when most wars happen within the international system. When defense and offense are almost indistinguishable, it will depend on what side has the slight advantage. If offense has the slight advantage, the possibility of an arms race increases due to the high probability of a security dilemma. For offensive realists, the security dilemma makes war rational and inevitable. When both offense and defense are indistinguishable, but defense appears to have the slight advantage, an arms race might take place. Defensive realists argue that defense has the advantage due to natural geopolitical variables, the morale of the defending citizens, and the cost of offense. National security is enhanced when no state can dominate the other state. If one state is stronger than others, that state will seek to dominate the weaker states. 
Currently, the U.S. has the defensive advantage around the globe. However, Russia is increasing their military capabilities in the Arctic, while the U.S. hasn't focused on building icebreakers or northern bases. Putin believes this gives Russia the offensive advantage in the Arctic region and Eastern Europe (Putin 2014, and Shlapak and Johnson 2016). Putin's land forces will seek to annex territory and control resources that don't initiate a response from NATO or the U.S. like he did in Ukraine and Georgia. An icefree Arctic will allow the normal American Navy to operate, shifting the balance back to the U.S. "The clearest sign that American exceptionalism has been decreasing is the aggressive and regional balancing dynamics taking place between states in the Arctic" (Murray 2012 p. 16). Russia has an incentive to use their military capabilities to increase their power since they have the regional offensive advantage. Jervis would argue this is when most wars break out (Jervis 1975). The explanatory framework of realism will falter in the region if Russia doesn't use the regional advantage to secure their goals.

Arctic states seem to have found themselves in a security dilemma: if they do not increase their military, there is a risk that a more powerful actor will try to exploit the weakness and threaten their regional interests. On the other hand, if they do increase their military, there is a risk that others may feel intimidated, and increase their capabilities. The problem is the lack of certainty about each other's actions (Atland 2014). The way to mitigate the Arctic security dilemma is Russia and the U.S.'s willingness to consider how their security moves in the region are perceived and increasing communication and proper signaling to reduce the risk of miscommunication (Atland 2014). 


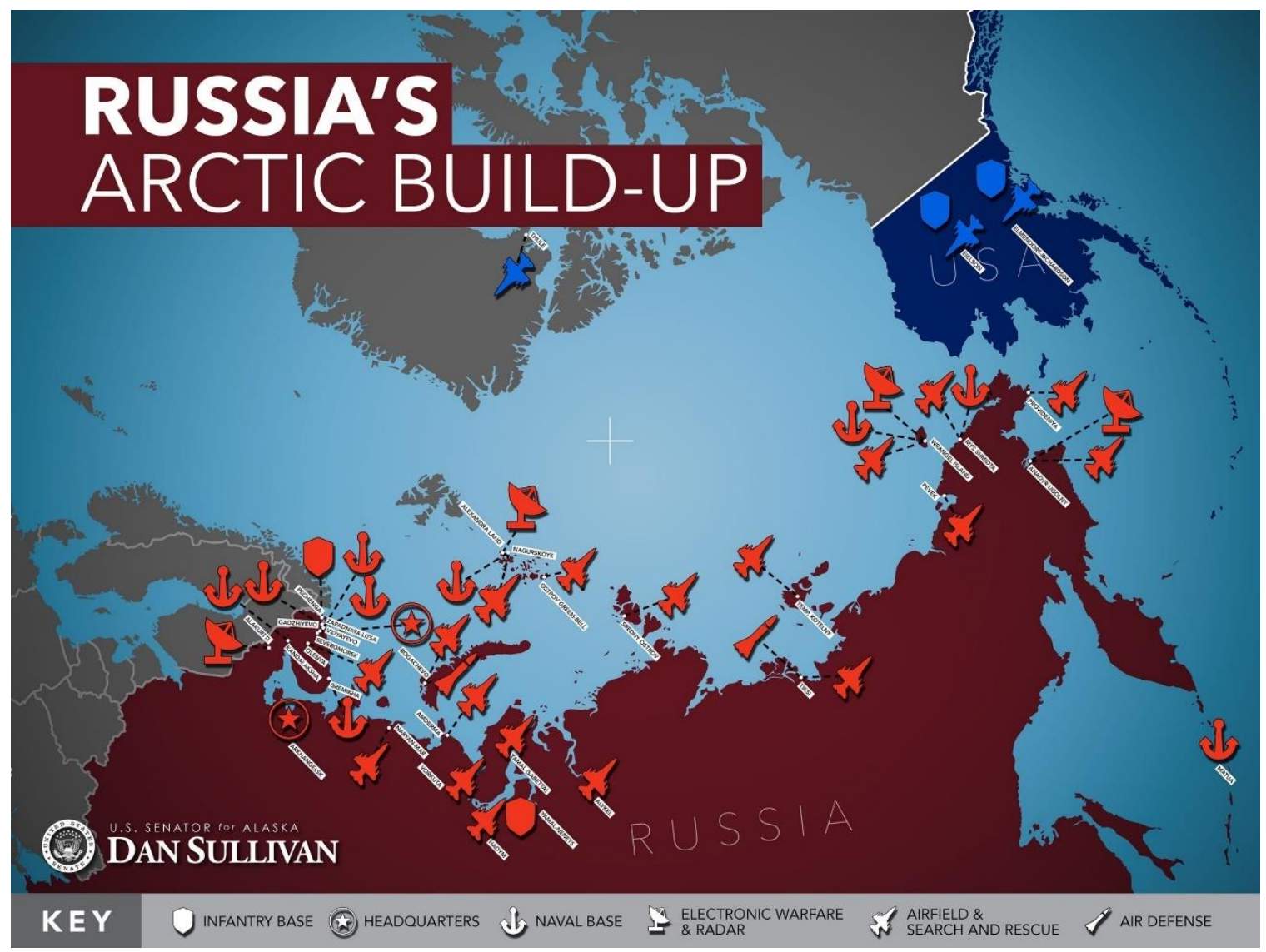

Figure 4 Russia's Arctic Build-up from (Gramer 2017)

Offensive realism is also concerned about a state's survival, but questions how much power states want. Mearsheimer argues there are almost never status quo powers (Mearsheimer 2014). States have incentives to gain power at the expense of other states. For both China and Russia, becoming the regional hegemon has increased benefits for their security and economy. Regional hegemony is low risk and high reward since the U.S. hasn't focused on the region since the end of the Cold War, and the abundant economic opportunities offered. Conquest or domination isn't the goal but does ensure a state's survival, so states should always be ready for opportunities to become the hegemon by increasing their power. Both Russia and China seek to gain power at the 
expense of the U.S. to become the regional hegemon. For both states, a new regional order would allow stability for development as states focus on increasing their economic gains, while war would hurt economic prospects.

For Mearsheimer, this makes strategic sense because when a state is in control of the system, the state can maximize their chance of survival. A state's power is calculated by the material capabilities it controls. The balance of power thus reflects the tangible military capabilities each state possesses. States also have latent power, based on the socio-economic variables that build military power. States can increase latent power by increasing their wealth or their population. Both China and Russia seek to increase their economy using the Arctic, allowing for latent power to increase military capabilities.

Mearsheimer argues, "the structure of the system forces every great power - even those that would otherwise be satisfied with the status quo to think and act when appropriate like a revisionist state" (Mearsheimer 2013 p. 74). When the great powers are content under the current system there is a period of peace. However, it is impossible to know another state's future intentions. States must assume the worst or concentrate on "the strategy of great power politics" (Mearsheimer 2013 p. 75) with absence authority. "Great power competition, not terrorism, is now the primary focus of U.S. National Security” stated Secretary of Defense Mattis (Ali 2018).

Mearsheimer argues the attacker has the advantage over the defender, as empirically, the state that starts the war, generally wins. The behavior of great powers also is more in accordance with offensive realism rather than defensive realism (Mearsheimer 2013 p. 77). Conquest sometimes doesn't pay, and offensive realists argue that states can be victorious without occupation. The winning state can annex part of the 
routed state, divide the state into two or more states, or disarm and prevent the state from rearming. With various territorial claims and a weak NATO (Shlapak and Johnson 2016), Russia has an incentive to annex Arctic territory, bolstering support for a realist framework.

Defensive realists calculate the difficulty to conquer territory in battle. States with high levels of nationalism are sometimes impossible to conquer because the citizens won't subjugate themselves to the occupying force. Defensive realists argue states should limit their appetite for power. If not, states risk their own survival since it is difficult to secure territory, and states will form a balance against the aggressor. However, defensive realists also argue great powers behave in ways that undermine their power, thus, the state doesn't act rationally (Waltz 1979). However, it appears that both the current U.S. and NATO plans are best explained by defensive realism. This is because the U.S. and NATO seek an appropriate amount of power in the region to ensure Russia doesn't feel insecure and start an Arctic arms race. "Being too aggressive in taking steps to address anticipated future security risks may create conditions of mistrust and miscommunication under which risks could materialize" (DOD 2010 p. 13). The U.S. DOD is wary of spending too much time, money, and effort in the region when there are other high risks security threats around the globe. However, Europe and the Arctic lack defensive capabilities that would be able to stop a quick attack by Russian forces (Shlapak and Johnson 2016) and as before, Russia could make a claim to protect Russian minorities while inundating a target with disinformation campaigns to quell backlash.

Flake argues that Russia's military build-up needs a proper historical perspective. While the increase has been considered a militarization of the region, it is a restoration of 
the Soviet-era force levels and useful to place within Russia's overall foreign policy (Flake 2017). The restoration allows Russia to claim sovereignty over its EEZ, protect their economic interest and retain their image as a great power (Konyshev and Sergunin 2014). Improvements to Russia's security and constabulary support their economic interests in developing resources and establishing the Arctic as a viable transit lane, helping Russia to establish their sphere of influence.

It is yet to be decided whether bipolarity is less war-prone than multipolarity. Jervis and Ikenberry believe bipolar worlds are less war-prone because there are more potential advantages for great powers to fight each other in a multipolar world. In a bipolar world, there is only one power dyad. In a multipolar world, there are three or more power dyads. Second, in bipolarity, the great powers are more likely to split the wealth and global population, evenly balancing the principal building blocks of military power. In multipolarity, the power building blocks might not be evenly distributed. Bipolarity balancing is more efficient since each power is balancing against each other. In a multipolarity world, two powers can balance against each other while the third tips the power to one side or the other. Due to the imbalance, there is greater potential for miscalculation in multipolarity, increasing the chances of war. During the Cold War, the Arctic was a bipolar arena, soon, the Arctic will become a multipolar region (Murray 2012) as China seeks regional influence and trade to evolve into a superpower. The key ratio is having an equal or indistinguishable amount of power between the most powerful states in the system. If one side has a lopsided amount of power, war is more likely to break out. Russia and China view each other as strategic partners and have plans for a Polar Silk Road under the One Road, One Belt initiative, causing a power imbalance, 
leaving the U.S. as the odd state out. For now, the marriage of convenience won't end in a divorce because the U.S. is the global hegemon, and both China and Russia are not able to separately develop the region. China needs energy, while Russia needs foreign investment, new mining technology, and markets. Once a state becomes sufficient, interdependence between the two states may exacerbate tension because the more dependent state may take advantage of the other state's weakness (Krickovic 2015). Jervis and Ikenberry would argue the potential power imbalance increases miscalculation and chance of war. "The world is changing and a number of trends that is challenging the United States, including the reemergence of great power competition, and not exclusively from the Russian Federation" (Donilon 2017).

Herz defines the security dilemma as groups or individuals concerned about their security in the anarchic world. States or individuals attain security to defend themselves to escape the threat of attack. However, this makes others insecure and compels them to attain more security, generating a cycle of power competition. None can ever be secure in a world of competing units and the power accumulation is a vicious circle of security (Herz 1950). States can increase their military strength but not actually increase their security at all (Herz 1951). Russia is modernizing their capabilities under the need of regional surveillance and resumed patrol flights, however, these can be considered as power projection and a strategic deterrence. Russia's military build-up might increase the speed of the spiral in the security dilemma towards conflict. Jervis adds the dilemma is caused by groups claiming their actions are defensive (Jervis 1976). "We are strengthening our military infrastructure in the region. Primarily this is done by restoring a number of airfields beyond the Arctic Circle and the military base on the New Siberian 
Islands. We are optimizing the army groups and naval forces in the area" while continuing to "invest heavily" in Arctic security (Putin 2014). However, this leads the U.S. and western states to view Russia as a threat (Gratz 2012), but the U.S. has been reluctant to focus on the Arctic and has decreased global military capabilities.

Without an Arctic pivot, the U.S. won't focus on the region, allowing the Arctic to avoid the security dilemma. However, the U.S. has started to focus on great power competition with Russia and China (Coats 2018), making an Arctic pivot inevitable. "The emergence of a multipolar systemic arrangement is very likely to increase security competition in the system, and the Arctic will be at the epicenter of such conflict" (Murray 2012 p. 9). Murray argues that the number of great powers in the system determines how stable or conflictual international politics will be. As the American hegemony wanes, the shift to multipolarity will increase tension and mistrust, altering stable Arctic relations (Murray 2012).

Tang believes there should be four more regulators: distance between actors, asymmetric power, allies or external actors, and the concentration/mixing of ethnic groups (Tang 2009). The regulators in the Arctic, which are the shortest distance between Washington and Moscow; the emergence of a multipolar world allowing China to tip the balance of power; the rise of asymmetric power particularly cyberwarfare; and information campaigns, add to the Arctic security dilemma. It's assumed China will ally with Russia, but other power dyads will leave a state out, tipping power away from the third wheel. A possible regulator is Russia claiming to protect Arctic indigenous groups or another group from the U.S./West as it did in Ukraine in 2014 and Georgia in 2008. 
Arctic states will find themselves in a security dilemma if Russia continues to militarize the region. If the U.S. and the West do not strengthen their military and security in the Arctic, there is a risk of Russia trying to exploit their weakness to create a sphere of influence that threatens Western interests. Alternatively, if the U.S. and the West strengthen their Arctic military, then Russia might feel insecure and threatened by the West's actions, eventually initiating the vicious circle of security (Atland 2014). The rhetoric and military build-up could produce a self-fulling prophecy, where states misperceive each other's actions and intentions (Brigham 2010). “The Russian military has increased the frequency of its exercises and maneuvers in the region, this quite often used phrase 'High North with low tension' might be replaced with its new version: 'High North with growing tension" (Luszcak 2017 p. 49).

Realists acknowledge that international institutions exist, and states operate within them. Realists argue that when states obey international law it is due to being in the state's interest to obey and encouraging other states to obey as well. This explains why regional agreements are created based on mutual interests such as environmental protection and search and rescue. States act within international institutions to help maintain or increase their share of world power, using regional and international governance when it allows them to coerce other states into action (Thompson 2006). Institutions are "arenas for acting out power relationships" and using soft power to achieve the desired outcome (Mearsheimer 1994 p. 13). "States spend significant amounts of time and effort constructing institutions precisely because they can advance or impede state goals" (Koremenos, Lipson, and Snidal 2001 p.762). 
For states to participate in international institutions, states must calculate their self-interest based on the distribution of power. Understanding the distribution of power makes it possible to explain the characteristics of the system and the behavior of states. As powers rise and fall, the international power structure will emulate the changes. Russia during the Yeltsin era participated in international institutions as a survival strategy. However, during the Putin and Medvedev era international institutions are used to improve Russia's international image and attractiveness (Joenniemi and Sergunin 2017). Arctic institutions with an absent U.S. allow Russia to act out a power relationship with regional states to advance Russian goals. Putin and Russia are trying to create a favorable Arctic system to establish a sphere of influence to maximize their survival. When the power realities of emerging powers are fulfilled, they historically trump any legal regimes and treaty structure (Kennan 1972). If the Arctic doesn't favor Russian interests based on international law, it appears Putin will use his regional advantage to secure Russia’s interests, bolstering support for a realist framework.

The Arctic has limited governance because states cooperate when it serves their interests. However, Mearsheimer argues there is little evidence of institutions changing state behavior, and it's especially weak in changing security concerns (Mearsheimer 1994). States fear that their cooperative behavior will be exploited even when they are under the auspices of an institution (Grieco 1985). Realists argue liberalism has little value when trying to explain issues that are conflictual when neither side has much to gain from cooperation (Mearsheimer 1994). Furthermore, Canada boycotted the Arctic Council meeting in 2014 due to Russian activity in Ukraine. Even though the Arctic has high participation in intergovernmental and regional organizations, none of the 
governance structures in the Arctic have a framework to deal with military or security issues (Heininen 2017). "Despite the widespread institutionalization of the Arctic and the quite effective soft-law regime supporting international cooperation, the region has not entirely escaped the geopolitical tensions emerging from the competition for using/controlling navigation routes" (Luszcak 2017 p. 36). Arctic organizations are actors, but states are still the principal decision makers. Arctic organizations will not have any significant effect on international outcomes if states remain the main actor (Waltz 1979). If Russia or the U.S. use military capabilities to solve a conflict because insufficient regional governance could not contain diverging interests, realism will be the better framework for explaining future Arctic relations.

States cooperate for two reasons: relative-gains considerations, and concerns about cheating. "The condition of insecurity - at the least, the uncertainty of each about the other's future intentions and actions - works against their cooperation... a state worries about a division of possible gains that may favor other more than itself" (Waltz 1979 p. 105-106). This argument questions how states view relative gains versus absolute gains. States that seek relative gains are concerned with how much power they have compared to their enemies and other states. States concerned with relative gains seek the most power to become the system's hegemon. States that seek absolute power don't care whether other states are gaining power, or how much power if they increase their power. These types of states are not motivated by the balance of power theory.

Currently, neither Russia nor China has the capital or technology to develop the Arctic. If Russia and China secure transit routes and resource claims, each state will have additional resources to increase their military and fund scientific/military research. These 
changes will shift the balance of power closer to Russia and China as their tangible military capabilities increase. "The most serious wars are fought in order to make one's own country militarily stronger, or more often, to prevent another country from becoming militarily stronger" (Carr 1946 p. 111). The U.S. should prevent the two states from accessing those resources and routes because they will have the relative-gains advantage over the U.S.

Executive Order 13685 sanctions Russian energy companies, defense companies and banks for Russia's aggressive actions towards Ukraine. Furthermore, the sanctions suspend foreign investments to any service or technology that supports deep-water exploration or could produce oil in any maritime area claimed by Russia. Mineral extraction tax and an oil export duty accounted for forty-six percent of Russia's tax revenue in 2014 (Golubkova, Lowe, and Elgood 2016), and increasing energy and oil sanctions will further impede future growth. The U.S. also placed limited sanctions on Chinese organizations over North Korea targeting oil exports. New sanctions could be used to limit Chinese Arctic development. By increasing sanctions on Russia and China, the U.S. could limit Arctic development by the two states, ensuring their relative-gains advantage doesn't shift the balance of power away from America. However, some Russians will view new or renewed sanctions as a declaration of war (Turak 2018). Without removing sanctions, Russia and U.S. cooperation will be limited, leaving the door open for continued Chinese investment and cooperation with Russia.

Security is based on power. Power can be distinguished between potential and actual power. Potential power is the number of citizens and the level of wealth. A good economy allows states to build formidable militaries (Carr 1946). The larger a state's 
population is, the larger the military can be. The state's army, and the quality of the air force and navy that support it, measure actual power. Since political control over land is the main objective of war, land forces are used to gain and control sovereignty over an area. Because an army can control land, Mearsheimer argues military might is still based on land power, despite the advent of the nuclear age (Mearsheimer 2014).

"With three great powers - the U.S., Russia and China - involved in the region, we may soon experience a clash of security cultures from cooperative security to a strategy of primacy or great power competition" (Lamy 2017 p. 96). The U.S. is already planning for "long-term strategic competitions with China and Russia" (DOD 2018 p. 4). The Arctic, however, will just be another geopolitical arena. States seek to protect their interests and create a sphere of influence without a binding security agreement. Weaker states in the region have either already joined with the U.S. under NATO's Article 5 or are attempting to pass the buck by having good diplomatic relations with both Russia and the U.S. States will continue to use Arctic institutions if the institution doesn't impede their interests or sovereignty, or the state can further their goals. Both Russia and the U.S. stated they would use unilateral action to protect their sovereignty and interests. States seek control of the region and resources, so it appears conflict is likely. 


\section{Chapter 3:}

\section{Arctic Background and Governance:}

Regional cooperation started during the Cold War with the Conservation of Polar Bears in 1973 by Canada, Denmark, Norway, the U.S.S.R., and the U.S. The treaty recognized the responsibilities and interests of Arctic states to protect the fauna and flora of the region (UNEP 1973). However, the science only focused on areas not deemed to be strategically significant during the Cold War, and furthermore, cooperation was typically in the form of data exchange rather than collaboration (Johnston 2002). In June 1991, Canada, Denmark, Finland, Iceland, Norway, Sweden, the U.S.S.R., and the U.S. signed the Finnish Initiative to implement environmental protection. However, the Finnish Initiative was criticized because it lacked direction, ongoing attention, and financial requirements. The initiative is soft law and lacked any legal authority and binding action (Young and Osherenko 1993).

The Arctic Council (AC) built on the Finnish Initiative to serve as a forum for cooperation and coordination among Arctic states and people. The Ottawa Declaration established the regional organization in September 1996.The AC included the initial members and added six Permanent Participants, including the Aleut International Association, the Arctic Athabaskan Council, the Gwich'in Council International, the Inuit Circumpolar Council, the Russian Arctic Indigenous Peoples of the North, and the Saami Council. The AC acknowledges indigenous people and wishes to respect their rights and interests while using the best available traditional and scientific knowledge to mitigate problems (Tromso Declaration 2009). 
Non-Arctic states have been approved for observer status since the AC formed. Observer states don't have voting rights. However, observer status allows states to propose and participate on projects, attend meetings and partake in discussions, engage with working groups while being able to make statements and submit documents on issues discussed. These states include China, France, Germany, India, Italy, Japan, the Netherlands, Poland, Singapore, Spain, South Korea, Switzerland, and the United Kingdom. The AC is the preeminent forum for addressing Arctic regional issues but remains a soft law institute. Agreements are reached through consensus, ensuring no state is outvoted or has a policy foisted upon them (Johnston 2002). Furthermore, the AC deliberately excluded military and security issues.

The Tromso Declaration in 2009 confirmed the rule of law and the Law of the Sea as a foundational framework for the AC. The Arctic Search and Rescue Agreement (SAR) became the AC's first binding agreement. The states entered into an agreement to cooperate in conducting search and rescue operations after the increase in Arctic maritime traffic and the harsh conditions posed. The states also recognized the importance of exchanging information and conducting joint training and exercises (Arctic Council 2011).

The AC agreement on Cooperation on Marine Oil Pollution Preparedness and Response in the Arctic was signed in 2013. The agreement is conscious of oil pollution to the vulnerable marine environment, and the livelihoods of indigenous and local communities (Arctic Council 2013). The AC established the Arctic Economic Council in 2014 to foster dialogue between businesses and the organization. The latest AC agreement is the Task Force on Arctic Marine Cooperation signed in 2015 to "assess 
future needs for a regional seas program or other mechanism, as appropriate, for increased cooperation in Arctic marine areas" (Arctic Council 2015 p.1). The Council hopes to implement an ecosystem-based approach for Arctic management that is flexible in order to meet changing circumstances.

The AC's strengths are the recommendations and reports on environmental protection, and transit. However, the AC lacks funding which limits resources and longterm planning, and there are few binding agreements (Finland 2010). "The United States has worked to make this institution work effectively in areas of low politics issues not directly related to national security" (Lamy 2017 p. 96).

The Conference of Parliamentarians of the Arctic Region (CPAR) is a biennial parliamentary body composed of delegations from national parliaments, NGOs, and other government officials of Arctic states, the European Parliament, and indigenous people. CPAR was originally designed to support the AC in 1994. Now, the Standing Committee meets a few times a year to discuss current Arctic issues and adopts conference statements for their biannual goals. CPAR's current conference statement focuses on transportation, education, research, human and economic development, and climate change.

The Arctic Five: Canada, Denmark, Norway, the Russian Federation and the U.S. adopted the Ilulissat Declaration in May 2008. The declaration called attention to the international legal framework, UNCLOS, already in place that provides the legal rights concerning the delineation of the continental shelf; the freedom of navigation; and marine scientific research for the Arctic. The Arctic Five believed there was no need to create a 
new legal regime to govern the Arctic since there was already a legal foundation in place (Ilulissat Declaration 2008).

Current boundary and resource disputes are mitigated through UNCLOS.

However, the U.S. has not ratified the convention, although the four other Arctic states ratified the convention. UNCLOS outlines state limits though EEZs. UNCLOS defines internal waters, territorial waters, contiguous waters, the exclusive economic zone, and a continental shelf.

Internal waters are all waterways within a state. States can regulate and use any resource within their internal waters without following international law. Foreign ships do not have a right to pass through internal waters without permission. Territorial waters extend twelve nautical miles from the state's coastline. The coastal state can set laws, regulations and use any resources within their territorial waters. Foreign ships have the right of innocent passage through these waters. Contiguous waters extend twenty-four nautical miles or another twelve nautical miles from territorial waters. In contiguous waters, states can enforce laws in four areas: customs, taxation, immigration, and pollution. EEZs extend 200 nautical miles from a state's coastline. A state has the sole exploitation rights over natural resources in their EEZ. States have sovereign rights but not full sovereignty in EEZs. Foreign states have the freedom of navigation and overflight. When EEZs overlap, states involved must delineate their maritime boundary through bilateral/multilateral agreements.

A continental shelf is a natural prolongation of the seabed to the continental margin edge or 200 nautical miles. If the natural prolongation exceeds the 200 -mile limit, the state can claim a continental shelf which extends 350 nautical miles from the 
coastline. States have resource rights within their continental shelf and have the right to exclude other states from those resources. However, the classification of a natural prolongation led to overlapping claims in the Arctic. The UNCLOS rulings and classifications will be important for states when they start to develop Arctic resources and might cause tensions between states.

NATO is starting to shift its focus to the Arctic - the first area of concern is navigation. The need for search and rescue capabilities increases with an estimated increase in human activity in the region. The second area of concern is natural resources and NATO's role in energy security. The third area of concern is territorial claims and the differences of opinion between the law regarding UNCLOS and the limits of a continental shelf. The final concern is Arctic states are strengthening their military capabilities (de Hoop Scheffer 2009).

"NATO provides a forum where four of the Arctic coastal states can inform, discuss, and share, any concerns...build trust and work towards cooperation when it comes to these issues. And that includes with Russia. There is a solid foundation of cooperation, until now, between the Arctic countries." (de Hoop Scheffer 2009).

NATO expressed interest in working with Russia on mutual concerns. However, recent Russian military posture is providing rationale for states to remain in NATO and providing motivation to increase NATO's defenses (Haftendorn 2017).

\section{Regional Arctic Cooperative Organizations:}

After World War II, the Nordic states wanted a Scandinavian collective defense alliance to be able to remain neutral and to defend itself if there was another great power 
war. The Scandinavian pact wasn't finalized due to the Finnish Paasikivi-Kekkonen policy and the Finno-Soviet Treaty of 1948 which created a mutual assistance pact between Finland and the U.S.S.R. The Treaty was designed for Finland to resist attacks by Germany or allies, which included NATO. The idea for a Scandinavian pact failed when Denmark, Norway, and Iceland joined NATO.

However, Scandinavian states formed the Nordic Council (NC) in 1952 to promote cooperation between Denmark, Finland, Iceland, Norway, Sweden and the autonomous regions of the Faroe Islands, Greenland, and the Aland Island. The NC created a regional labor market, passport-free travel, and focused on public health and culture. The Council shifted its focus to environmental protection in the Baltic Sea and the North Atlantic in the 1980s (Nordic Council 2017).

The Nordic Council of Ministers is an institution set up to supplement the Nordic Council. The members include Denmark, Finland, Iceland, Norway, Sweden and the autonomous areas of Greenland, Faroe Islands, and Aland. The Helsinki Treaty regulates it, and decisions are made by consensus and are binding (Finland 2010).

The Kirkenes Declaration established the Barents Euro-Arctic Region (BEAR) in 1993. The goal of BEAR is to increase cooperation on sustainable economic, social, and environmental development. BEAR believes cooperation can secure long-term stability and reduce any tension since the region had strain due to possible military confrontation during the Cold War. The member states are Denmark, Finland, Iceland, Norway, Russia, Sweden and the European Commission with representatives from the Saami, Nenets, and the Vepsian indigenous peoples (BEAR 2017). 
The European Union is an Arctic institution via Denmark, Finland, and Sweden while Norway and Iceland are members of the European Economic Area. The EU argues they have rights and obligations to the Arctic under international law (European Parliament 2014). The EU is concerned about environmental problems, economic development, and trade routes. The EU stresses climate change will cause unprecedented security scenarios.

The EU argues climate change will cause conflict over resources and energy supply, damage to coastal cities and infrastructure, border disputes, environmentallyinduced migration, and situations of fragility and radicalization (European Council High Representative and the European Commission 2008). In 2008, the EU Parliament proposed a global Arctic strategy to ensure equal access to natural resources (European Parliament 2008). However, the EU is also concerned about energy security and their growing demand for imported oil and gas. Energy sources are coming from fewer states, and those states have stability issues (EU Commission 2008). "In addition, the increased accessibility of the enormous hydrocarbon resources in the Arctic region is changing the geo-strategic dynamics of the region with potential consequences for international stability and European security interests" (European Council 2008 p.8).

Later in 2008, the EU released another report focused on three objectives: protecting and preserving the Arctic in unison with its population, promoting the sustainable use of resources, and contributing to multilateral governance. The EU believes cooperation with Norway and Russia will foster sustainable development of resources, and cooperation helps with the observance of environmental protection (Commission of the European Communities 2008). For Europe, a stable Arctic with 
responsible and sustainable development can create new opportunities for entrepreneurial activities (Council of the EU 2009). Nevertheless, Javier Solana, the EU High Representative for the Common Foreign and Security Policy, warned in 2008, that Europeans should prepare for conflict with Russia over energy sources (Alexandrov 2009).

The Northern Dimension (ND) focuses on stability, and sustainable development through regional cooperation with the EU, Norway, Iceland, and Russia. The U.S. and Canada are observers to the organization. The European Arctic has intergovernmental cooperation, as the ND works with the Council of the Baltic Sea States, Barents EuroArctic Council, the Arctic Council, and the Nordic Council of Ministers to achieve regional goals by working together on joint priority topics, and communication practices to avoid overlap in services (Northern Dimension 2017).

The six Arctic organizations seek to create regional standards to foster long-term cooperation through mutual interests. Arctic states have similar interests in SAR, preventing ecosystem damage, mitigating the effects of climate change, and increasing economic development. Axelrod and Keohane can best explain how mutual interest in the region helps regional organizations flourish. States involved in regional organizations receive an absolute gain. The creation and growth of Arctic governance provides evidence that the Arctic can adhere to international norms to foster a stable region. However, a realist would argue states act within Arctic organizations to increase their share of power and states only cooperate on mutual interests while security issues don't have a framework to ensure regional peace. 


\section{Domestic Arctic Policy:}

\section{United States:}

The U.S. has spent little time developing a foreign and defense strategy for the circumpolar region and has been reluctant to be an Arctic power (Huebert 2009). The first U.S. Arctic policy focused on three objectives: natural resources, the recognition of the fragile environment, and need to better understand the environment (White House 1994).

The U.S. released the National Security Directive (NSPD-66) focusing on the Arctic region in 2009. The directive explained core national security interests including missile defense and an early warning system for strategic deterrence, the deployment of sea and air systems for sea lifts and ensuring freedom of overflight and navigation especially in the Northwest Passage and the Northern Sea Route.

"The United States has broad and fundamental national security interests in the Arctic region and is prepared to operate either independently or in conjunction with other states to safeguard these interests" (White House 2009 p.3). The U.S. seeks peaceful resolutions of disputes in the area over military conflict. However, the U.S. may exercise its sovereign right over the natural resources within the American extended continental shelf and boundary, since energy security is a national interest (White House 2009). The Navy believes the area is a low-security threat, which will allow states to resolve problems peacefully. However, the Navy is ready to prevent conflict, and protect national interests (U.S. Navy 2014). The Arctic is "where we seek to meet our national security needs" (White House 2013 p. 50). 
With recent Russian violations of sovereignty in Ukraine, Georgia, and Moldova, the Department of Defense (DOD) committed to invest and improve the posture of American forces to deter and strengthen U.S. capacity to defeat aggression in the Arctic. The DOD will continue to develop and increase NATO and military alliances while training in the region to identify strengths and weaknesses of operating in a polar environment (DOD 2016). However, the DOD cautions of spending too much time, money and effort in the region with other, high threat risks and austerity. The DOD is also aware of increasing militarization as "being too aggressive in taking steps to address anticipated future security risks may create the conditions of mistrust and miscommunication under which such risks could materialize” (DOD 2010 p. 13).

The U.S. recognizes the unresolved boundary dispute with Canada over the Beaufort Sea and defines the boundary on equidistance (White House 2009). Canada and the U.S. are strategic partners and will continue to work together in NATO and NORAD (North American Aerospace Defense Command) to provide homeland security and defense. Both states recognize their relationship and common interests they share. The defense cooperation between the two states is "important to our mutual security interest in the Arctic", and the U.S. stresses the "unique and enduring partnership" (US Navy 2014 p. 7). So, it appears the U.S. won't publicly challenge the boundary dispute.

The U.S. is cautious when engaging with multilateral organizations, and prefers to act unilaterally, or in a coalition of similarly minded states when it's in their best interest. "It is the position of the United States that the Arctic Council should remain a high-level forum devoted to issues within its current mandate and not be transformed into a formal international organization particularly one with assessed contributions" (White House 
2009 p. 4). It appears the U.S. is willing to work within Arctic organizations, if it favors an American agenda, but currently unwilling to grant them more power which might limit U.S. sovereignty. However, the U.S. supports the principles established by UNCLOS and wishes to preserve all rights and freedoms of the sea and airspace granted by international law.

"The Arctic region is the last global frontier and a region with enormous and growing geostrategic, economic, climate, environment, and national security implications for the United States and the world," stated Secretary of State John Kerry (U.S. Embassy of Norway 2015). America's Arctic policy is based on defending their national security and energy interest in the region. Also, America is willing to work with others or within organizations, if it favors them. However, the U.S. is also willing to use unilateral force when necessary.

\section{Russia:}

"This region has traditionally been a sphere of our special interest. It is a concentration of practically all aspects of national security - military, political, economic, technological, environmental and that of resources," stated Russian President Vladimir Putin (Putin 2014). Former Russian President, Dmitry Medvedev, stated "the Arctic is crucial to Russia's future", as a strategically significant area. The increased revenue from developing the Arctic would stimulate the Russian economy. "Our first and main task is to turn the Arctic into a resource base for Russia in the twenty-first century" (Seattle Times 2008). The Kremlin has a dual message concerning the Arctic - internationally, Russia stresses cooperation and peace, while domestically, Russia is signaling a nationalist message of a resurging great power with revanchist undertones. "Russia seeks 
to maintain the role of a leading Arctic power" (Heininen, Sergunin, and Yarovoy 2014 p. 9).

Russia plans on developing the Arctic as their natural resource base between 2016 through 2020 and develop Northern Sea Route infrastructure (Russian Federation 2009). Russia would like to increase cooperation in the region through existing international organizations. Currently, Russian officials believe they can best secure their interests through cooperation and not conflict (Flake 2017). However, Russia would like to maintain a favorable operative mechanism in the Arctic for national security and border protection (Russian Federation 2009).

In 2013, Putin released a new Arctic strategy, acknowledging that numerous goals from 2009 were not met. Putin planned to reformulate the Arctic strategy since Russia lacked both the technology to develop natural resources and the foreign capital to invest in regional projects (Putin 2013). Russia is strengthening itself against new threats and "is giving rise to opposition from the United States and its allies, who are seeking to retain their dominance in world affairs" (Russian Federation 2015 p. 3). Russia claims NATO’s buildup is a threat to their security, and opportunities for global stability are shrinking as the U.S. deploys their missile defense system.

"It's crucially important for us to set goals for our national interests in this region, if we don't do that, we will lose the battle for resources, which means we'll also lose in a big battle for the right to have sovereignty and independence," stated Russian Vice Prime Minister Dmitry Rogozin (Tharoor 2015). Russia grounded their extended continental shelf (ECS) claims in international legal precedent and is working within the international framework to mitigate any possible conflict. The Russian-Norwegian Barents Sea 
agreement, though not finalized, and the Soviet Svalbard Treaty demarcate Russia's Arctic territory.

Russian Arctic fleets atrophied after the Cold War since it was no longer a strategic priority or economically viable. Russia's northern military improvements since 2008 include restoring air posts, strengthening air and sea defense, and creating two Arctic brigades under the new Arctic command structure. These upgrades are a restoration to Soviet-era levels (Flake 2017).

Russia still has an aversion for NATO and finds the alliance's plan to move closer to the Russian borders as unacceptable. They worry that an ice-free Arctic will open new sea lines of communication, and America's emphasis on the freedom of navigation will attract NATO warships and foreign navies into the Russian EEZ. Russia also perceives a military and economic imbalance between them vis-a-vis America and NATO. However, Russia feels they have an escalation and localization dominance in the Arctic region due to its coastline, icebreaker fleet and military strength in the region. While the overall power of balance favors NATO and the West, Russia believes the regional balance of power tilts towards them. Russia is prepared to use its military if its interests are threatened (Russian Federation 2015).

Russia's Arctic policy is based on their preference to work within international organizations and law to further their agenda to "overcome the trauma of the collapse of the Soviet Union, the fear of becoming a fragmented country, and a failing state (Laruelle 2014 p.254). However, Russia worries about NATO and the West's power in the region, and is willing to use force if Russian interests are threatened.

\section{NATO allies:}


Due to NATO's Article Five for the common defense of every member, the U.S. could become involved in a conflict over allies' sovereignty and national security interests. Stephen Harper made Arctic sovereignty and security part of his election platform when he ran for Prime Minister in Canada. He proclaimed, "You don't defend national sovereignty with flags, cheap election rhetoric or advertising campaigns. You need forces on the ground, in the sea, and proper surveillance" (Harper 2005). Canada asserted that the military's role increased to deter threats and protect the resource-rich area with the release of the Canada First Defence Strategy.

Denmark believes the threat of a conventional military attack is low. However, Europe has become less secure with threats of fragile states, and Russia's actions seek to undermine the European order. With new threats, Denmark has a need for military cooperation and to ensure NATO is a deterrent by working to meet their funding commitment (Denmark 2016). The Thule Air Base in Greenland is an important NATO military infrastructure in the region.

Currently, Denmark and Russia have overlapping ECS submissions. Denmark claimed an area that stretches into Russian territory in 2014 while seeking a large EEZ to grow their economy (Denmark 2011). It is estimated that within Greenland's EEZ are 31 billion barrels of oil, and it is rich in mineral deposits, including nickel, zinc, gold, and rare earth elements (Denmark 2011 p. 24). Both Denmark and Russia claim the Lomonosov Ridge as extending from their own tectonic plates, possibly causing tension when UNCLOS issues a ruling. Because Denmark is a NATO member, this could be a reason for the U.S. to become involved in a conflict with Russia as NATO tries to protect Denmark's ECS claim or their resources. 
As a state without any military forces, Iceland relies on the U.S. Defense Agreement of 1951, and NATO for security (Iceland 2011 p. 6). Iceland increase security and political cooperation with Nordic states and the EU after the U.S. temporary pulled out their defense capabilities in 2006. Iceland believes the U.S. is still the sole superpower, but other states are becoming evenly matched. The global balance of power is changing, and the Arctic region is not an exception (Iceland 2011).

Norway has economic ties to Russia and seeks to maintain cooperation, but Norway is also a member of NATO. Former Norwegian Foreign Minister proposed a joint Nordic force in 2009 within the NC to ensure security, allowing navies and air forces from Denmark, Norway, and Sweden to patrol the region (Alexandrov 2009). Russia assists Norway with surveillance, border patrol, and sovereignty claims. However, Norway also participates in NATO exercises to strengthen and integrate capabilities. Norway recognizes its membership in NATO is the cornerstone of their defense. However, Russian military operations in the area increased since the 2000s. Norway does not consider the Russian military build-up as targeting them but is a factor due to its NATO membership. Norwegian Armed Forces will exercise sovereignty and authority to protect their interest (NMFA 2017 p. 18). Norway's alliances might lead them to pick a side if tensions rise between NATO and Russia in the Arctic or elsewhere around the globe. It appears Norway would favor Russia in any Arctic conflict due to geopolitical proximity and close relations with Russia. Norway leaving NATO would undermine the organization's mission and increase Russia’s power and legitimacy in the region.

Finland is an Enhanced Opportunities Partner (EOP) in NATO but seeks to achieve their objectives through intergovernmental cooperation due to their relations with 
other states and indigenous groups. Finland is hedging that Norway and Russia's energy development in the Barents area will require Finnish expertise. "Russia's active participation in measures contributing to common goals is of special importance for Finland" (Finland 2010 p.14).

Each coastal state has an interest in protecting their sovereignty and national security. However, the smaller powers are unable to defend themselves against the great powers in the region. All states besides Finland and Russia are protected under NATO's Article Five. Norway has ties with both Russia and NATO, and if a conflict arose, it appears Norway would side with Russia. Norway leaving NATO would further Russia's goal of undermining Western institutions. Finland would most likely follow Norway into the Russian sphere of influence due to its ties to both Norway and Russia, and proximity. Non-Arctic States:

States outside the Arctic seek to increase their influence in the region for access to transit routes and natural resources. The non-Arctic states that participate in the AC as observers include China, France, Germany, India, Italy, Japan, Netherlands, Poland, Singapore, Spain, South Korea, and the United Kingdom.

\section{China:}

In 2010, Chinese Rear Admiral Yin Zhuo stated the "Arctic belongs to all the people around the world as no nation has sovereignty over it" (Wright 2011 p. 2). The Arctic has vital interests for states outside of the region (PRC 2018). A new term "EightState Polar Region Alliance" (Jidi baguo lianmeng) is how China describes the AC, referring the current situation to that of the "Eight-State Allied Forces" (Baguo Lianjun), reminiscent of the Boxer Rebellion (Wright 2011). China believes the Antarctic and the 
Arctic involve China's international rights, and that China should safeguard against any infringement of those rights and protect the common interest of all states.

China is concerned the Arctic is going to be carved up by western powers to share the resources and exclude everyone else (Wright 2011). China advocates for a stable Arctic based on international law to benefit all actors. However, China became a permanent observer in the AC, strengthening Beijing's position in the region. Beijing's objectives in the north include participating in regional governance, gaining access to shipping routes and natural resources, and participating in scientific research. China stresses that all states are granted the freedom to conduct research and the freedom of navigation in the Arctic (PRC 2018). There are plans for the One Belt, One Road to expand via the Polar Silk Road allowing China to ship around both the northern and southern flanks of Eurasia. China supports enhancing security to ensure the safety of tourists for the emerging Arctic tourism industry and as a source of tourism (PRC 2018).

The non-Arctic state is interested in energy resources as Chinese companies have deals to explore in Iceland and Greenland. China also has deals with Russia's Rosneft. The Sino-Russian partnership is mutually beneficial as China gains a source of oil for their growing consumption, and Russia receives funding after Western sanctions isolated them. China sees Russia as a strategic partner (Wright 2011). China seeks a position to develop Arctic resources and the legal framework to regulate transit routes. China also wants to study climate change, and the impact the climate will have on the Chinese environment.

Arctic states' strategies are to safeguard their sovereignty and secure their share of resources. China prefers to claim the Arctic as a global commons and seeks to increase 
their participation in regional cooperation (Haftendorn 2011). Each state stated they wish to protect the environment, increase Arctic governance and conduct research. 


\section{Chapter 4:}

\section{Foreign policy analysis:}

A foreign policy analysis focuses on how states are self-interested and what factors such as military capabilities, domestic institutions, economy, and political factions influence the actions states take (Halliday 2005). A state's capabilities are defined by the number of weapons, arms production, soldiers, and trade it has (Heininen 2017). "The greater a state's total resources (e.g., population, industrial and military capability and technological prowess), the greater a potential threat it can pose to others" (Walt $1989 \mathrm{p}$. 19). The old aim of the U.S. grand strategy is to prevent any single state from controlling more raw resources than the U.S. controls. This strategy will lead to conflict over oil, natural gas, and possibly rare earth elements in the Arctic to prevent Russia and China from having a favorable balance of power.

Security is based on power. Power can be distinguished between potential and actual power. Potential power is the number of citizens and the level of wealth. A good economy allows states to build formidable militaries. The larger a state's population is, the larger the military can be. Actual power is measured by the state's army, and the quality of the air force and navy that support it. Since political control over land is the main objective of war, land forces are used to control and annex an area (Mearsheimer 2014). Great powers are strong because they control resources allowing them to generate and maintain power at tactical and strategic levels. A state's interest and military capability will allow for a complete understanding of future Arctic international relations.

The People's Liberation Army has 2.3 million active duty soldiers with another half a million in reserves drawn from a population of 1.3 billion, while the U.S. has 1.4 
million active duty soldiers drawn from a population of 323 million (Rinehart 2016). The Russian Armed Forces have 1.9 million active duty soldiers (Pravda 2017) drawn from a population of 144.3 million (World Bank 2016). The U.S. has the largest military budget at $\$ 587$ billion, followed by China with a defense budget of $\$ 146$ billion (Rinehart 2016), followed by Russia with a defense budget of \$58.9 million (IISS 2017). Altogether, NATO consists of 2 million soldiers including American troops drawn from the twentynine members. NATO’s defense budget was $\$ 892$ billion with $\$ 265$ billion spent by European members in 2016 (NATO 2017).

The DOD estimates China has a nuclear arsenal of 200-300 warheads. (Rinehart 2016) Due to the new START Treaty going into effect in February 2018, both Russia and the U.S. are limited to 700 deployed missile carriers divided between ICBMs, submarines, and bombers, while each state is limited to 1,550 deployed warheads (Department of State 2010). However, non-deployed missiles don't count against the limit.

The three states rank first through third in active duty soldiers and defense budget. Russia and the U.S. possess the most nuclear weapons, while China has the fourth most warheads. China and the U.S. have the two largest economies, while Russia hopes to rebuild their stagnant economy. These factors allow each state to pose a large potential threat to each other. Every state also has potential power and actual power to maintain their security and protect their interests.

\section{Arctic security strategies:}

Arctic security changed since the Cold War with the growth of regional governance, the increase in cooperation with indigenous groups and sub-national 
governments, and the increase in relationships between regional and global actors. However, these factors don't rule out the militarization of the regional or a future Arctic conflict. "The geopolitical and strategic importance of the Arctic region is growing, as symbolized by the planting of a Russian flag on the seabed below the North Pole" (European Parliament 2008). However, there are two defined but opposing discourses on Arctic geopolitics. One discourse is based on liberalism, focusing on peace and stability in the region through institutionalized regional cooperation via the $\mathrm{AC}$, the $\mathrm{UN}$, and other organizations. The second is the realist perspective, arguing there is a race for natural resources and economic interests that will produce regional conflicts (Heininen, Sergunin, and Yarovoy 2014).

The U.S. worries that international institutions would negatively affect its defense strategies in the Arctic and limit its sovereignty, so the U.S. prefers to work unilaterally or bilaterally regarding Arctic issues. Russia wants to expand Arctic governance in the AC while the U.S. views the council as a forum to discuss ideas. The U.S. does not want to consider the $\mathrm{AC}$ as an international organization and give it the power to create binding resolutions. However, the U.S. supports the growth of NATO and increasing NATO's capability in the Arctic (Heininen, Sergunin, and Yarovoy 2014) While security growth through NATO might empower four of the Arctic states, it will leave Russia feeling threatened (Huebert 2009). The U.S. is avoiding creating new institutions in the Arctic that would decrease their global power, thus slowly working through existing institutions or treaties. States are concerned about the global distribution of power, "the most powerful states in the system create and shape institutions so that they can maintain their share of world power, or even increase it" (Mearsheimer, 1994/5 p.13). Institutions 
are places for states to act on power relations, which explains why the U.S. is reluctant to increase Arctic institutions and wants flexibility for their actions while Russia and China seek to increase Arctic institutional power.

The Arctic has geopolitical tension because the region has multiple unresolved territorial conflicts, an ill-defined legal framework, undeveloped energy resources, and increasing environmental concerns. Russian officials argue the U.S. and NATO have increased Arctic military and political pressure. Russia is facing four other Arctic states which are members of NATO making the security configuration unsettling (Flake 2017). They believe the West is trying to undermine Russia and reduce Russian presence in the area. Russia is concerned that an ice-free Arctic would allow the U.S. to permanently deploy a submarine fleet and a sea-based ABM (antiballistic missile) system (U.S. DOD 2013). Huebert argues that despite states downplaying military conflict in the Arctic, investments in military capabilities between Arctic states increase the competition, thus possibly creating an Arctic arms race (Huebert 2010). "The longer there is an ad-hoc approach to Arctic security, the greater the risk of misunderstandings, miscommunications and accidents in this dark, ice-covered and hostile region" (Conley 2011).

“Current Russian policies in the Arctic are explained by Moscow’s pragmatic interests such as competition for natural resources and/or control of northern sea routes" (Heininen, Sergunin, and Yarovoy 2014 p.4). Russia recognizes a need to increase their northern military capacity to meet existing and predictable threats as well as protect their sovereignty claims. Russia, however, will take a dual approach by also working to "improve the legal framework in the area of developing the foundations of governance of 
the Arctic zone of the Russian Federation" (Putin 2013 IV:24). Russia will use both diplomacy/international law and military force when it suits their needs. Moscow represents an amalgamation of Soviet/Peter the Great Russian revisionism, soft power, and using international law in its favor. Russia will seek international cooperation to develop the Arctic, rather than take unilateral military action while they are rebuilding their economy and military.

The Bering Strait will become strategically important as a chokepoint for vessels. The Strait allows Russia to connect Asia and Europe and will serve as an important route for trade (U.S. Navy 2014). The U.S.S.R. in 1990 declared the Northern Sea Route is situated between inland waters and their EEZ, and thus could regulate navigation to ensure safety and to prevent environmental problems. Vessels seeking to travel the route must request a travel permit and an icebreaker for guidance (U.S.S.R. Minister of Merchant Marine 1990). The regulations increased as hydrometeorological and ice condition services were added in 2016. Both laws stress regulations that are pertinent to safe navigation in the harsh region. However, the U.S. Navy maritime strategy identifies the freedom of navigation as the top U.S. national priority and rejects Russia's claim of the passage. The preservation of the rights of Arctic navigation and overflight allows the Navy to exercise these rights throughout the world (Titley and St. Johns 2010 p. 42) and could be a possible point of tension.

Canada is building a military base on the Northwest Passage to protect their sovereignty in the Arctic. However, Canada does not have the forces to defend against a large-scale conflict and rather relies on the U.S. for defense. Canada and Russia have a history of bilateral cooperation dating back to 1992. Together, the two nations cooperate 
on soft security threats like climate change and pollution, maritime safety, illegal migration, organized crime, and terrorism. However, security cooperation ceased to exist due to the Ukrainian conflict. Increasing tensions in Ukraine could spill over to the Arctic region between the two states (Heininen, Sergunin, and Yarovoy 2014).

Putin agrees that the U.S. is the current dominant power controlling the status quo. However, Putin argues once another great power emerges, the balance of power is ruined. Putin advocated for challenging the U.S. and the West to reduce their dominance of international affairs (Russian Federation 2015). From the Russian perspective, a new balance of power is better, while it would be worse for the U.S. and other NATO allies. NATO believes it has striven to foster cooperation with Russia through the NATO-Russia Founding Act and other international organizations. Russia, however, violated its commitments and international law. NATO does not want conflict with Russia but will not let Russia violate the principles and security of the alliance (NATO 2014). Norway's Joint Military Headquarters Commander, Rune Jakobsen stated, "We are not in a conflict with Russia, and we have never had a border dispute with them in 1,000 years, but after Ukraine, we changed our posture." Russia is developing new military capabilities, and if Norway leaves a vacuum, Russia will fill it (Wintour 2017). Furthermore, Russia is actively challenging Western dominance by driving wedges between institutions and populations, while creating doubt about those institutions.

Chinese interest can be understood by the deficit of domestic energy resources and the abundance of natural resources in the Arctic. China, the top global exporter, is interested in shorter transit routes that avoid the Singapore Strait, the Strait of Malacca, the Horn of Africa, and the Suez Canal. Both the Northwest Passage and the Northern 
Sea Route are about half the distance between Asian exporters and Western European ports compared to current routes. These passages also hold geopolitical and strategic importance for global navies.

An ice-free Arctic would continue Russia and China's recent cooperation. Within the last decade, the two states traded energy and weapons; conducted a joint-naval exercise in the Baltic Sea; held a summit in Moscow; and signed a roadmap for military cooperation (Wu 2018), while Beijing didn't expel Russian diplomats after the UK nerve agent attack (Westcott 2018). Historically, the two states tend to vote in tandem and hold veto power in the UN Security Council. Also, Russia is currently the highest recipient of Chinese foreign aid between 2000 and 2014 (Taylor 2017). China was the largest importer of Russian arms between 1999 and 2006, and they resumed weapon trade in 2015 (Wezeman 2017).

The two view each other as strategic partners, while Chinese Foreign Minister Wang Yi stated, "Relations were at the best level in history" ahead of Putin's visit to Beijing (Westcott 2018). China would be able to export goods to Europe via a faster, safer region that Russia would patrol. China would also be able to increase the import of Russian energy after developing regional infrastructure. "China seems to see the overall effect of Arctic climate change as more of a beckoning economic opportunity than a looming environmental crisis" (Wright 2013 p.1). Under this scenario, China would have the relative gain over the U.S. and thus the Chinese would be able to increase Russia's gains, possibly allowing Russia to have the relative gain advantage over the U.S. Unless the U.S. can keep China out of the Arctic, China will have the relative gain advantage, leaving the U.S. at a disadvantage. 
Russia and China both seek energy security for economic development. Krasner argues that American national interests shape energy policy. The U.S. has three clear goals in shaping their claim to natural resources: develop policies to maximize the competitive structure of the global market and thus keep the prices of key commodities low; increase the security of supplies of critical natural resources on which the U.S. depends on for economic and political security and stability; and implement policies that help secure more general foreign and security policy objectives (Krasner 1979 p. 331). Due to the three American goals, Russia's and China's need for energy will cause tension between the three states. Energy security is strategic, and the more credible options a state has, the more power it wields (Heininen 2017). Norway and Russia together provided around seventy percent of petrol, and fifty percent of the oil imported into Europe. Russia supplies about twenty-five percent of imported coal as well (Finland 2010). Due to these factors, the EU seeks cooperation with Norway and hopes that they become a member. This leaves the U.S. to worry about European energy security. "What matters most is the number of great powers and how much power each control." If the power ratios between the great powers are not lopsided, the chance of military conflict is low (Mearsheimer 2014 p. 337). However, once China starts to expand to the Arctic, China will become the tipping point creating a multipolar Arctic.

Each state in the Arctic has their own security and economic interests. However, the militarization of the Arctic is low, which gives time for states to work on their interests without the threat of military conflict. 


\section{Chapter 5:}

\section{Two theories in Arctic relations:}

\section{Liberalism:}

The development of natural resources reinforces Arctic governance because Russia and others have more to lose economically if they go to war (Brigham 2011 and Staun 2017). There is an important role for international agreements like UNCLOS and international organizations like UNCLCS and the AC to mitigate conflict, especially for the development of energy resources and transit networks (Wang 2012). Arctic institutions have greatly increased since the end of the Cold War, creating an order and hierarchical structure through frameworks and norms. These institutions bring states together to cooperate on issues such as environmental protection, search and rescue, and economic development. Other forms of Arctic governance created a regional labor market with passport-free travel, increased public health and education, and raised awareness for indigenous culture while securing long-term stability.

It is beneficial for all states to follow the norms and standards to foster stability in the Arctic. By growing governance, Arctic shipping routes can be safely used, while resources are developed in a sustainable fashion. The reduced transaction costs will increase sharing of information, helping to mitigate the fear of defection.

All states in the Arctic have a common interest in economic development and environmental protection, thus increasing cooperation in those areas (Axelrod and Keohane 1985). Even rivals during the Cold War recognized the need for protecting the ecosystem by signing the Conservation of Polar Bears in 1973, the Finnish Initiative in 1991, and the Tromso Declaration in 2009. When states benefit from cooperation, states 
will form institutions to normalize the relation (Keohane and Martin 1995) fostering interdependence (Lipson 1984). States and actors started this process after World War II but made little progress during the Cold War. Regional governance increased since the 1990s, but still only has two binding treaties. Due to the lack of binding treaties, and the absence of security issues discussed, the $\mathrm{AC}$ was able to operate normally during and after the Ukrainian Crisis (Byers 2017). Exner-Pirot argues that states should use the opportunity after SAR to increase cooperation to reduce the possibility of miscommunication (Exner-Pirot 2012).

Stokke argues that knowledge-building and capacity serve the AC and regional institutions well, while norm-building and rule enforcement is dealt with more effectively by other institutions (IMO or UNCLOS), but regional organizations can add support. Furthermore, the AC has obtained results between the West and Russia because knowledge-building is considered non-controversial (Stokke 2012). Post-Cold War region governance focuses on mutual interests and opportunities (Byers 2017).

Every state policy recognizes the need for environmental protection. The states are willing to cooperate with scientific research to mitigate the problem. Organizations and regimes can build on already established mutual interests to continue to foster interdependence to normalize regional relations. The establishment of the Arctic Economic Council in 2014 will help foster private-public partnerships and bring in regional investment to strengthen Arctic stability. Regional regimes and institutions will reinforce reciprocity, making defection costly for actors and decreases future economic gains. Flake argues the increase in regional governance, and Russia's willingness to be diplomatic by signing search and rescue agreements, pollution agreements, and oil-spill 
agreements help support Russia’s strategic economic interests (Flake 2017). Russia also actively worked to peacefully resolve border disputes to free up administrative capacity to focus on other issues (Moe et al. 2011) If states can continue to build on linked agreements the regional governance structure will foster complex interdependence to reduce the possibility of conflict. The U.S. and Russia will also have to resolve the easy disputes (Flake 2017) to stop a spillover effect in the Arctic. Those easy disputes of Syria, Ukraine, and the Lomonosov Ridge are easier talked about than settled as each has geopolitical and economic consequences.

The U.S. has supported bilateral and multilateral agreements with other states described as "architecture without building" (James and James 2014 p. 200). Canada and the U.S. signed the Arctic Cooperation Agreement of 1988. The U.S. wouldn't recognize Canadian sovereignty claims, but the U.S. would still ask Canada for permission before transit. The U.S. also established NORAD and the Tri-Command Framework with Canada to coordinate security between the states (James and James 2014). Regional complex interdependence also increased with fisheries management agreements, arms treaties, created "epistemic communities of professions" through research collaboration, and infrastructure investment by domestic and foreign sources, adding support to Young and his multiple agreements to increase regional governance.

The dynamics of Arctic politics could change with Trump's Russian connections. This might allow Russia and the U.S. to seek better relations around the globe and in the Arctic due to mutual interests. Trump's appointment of Rex Tillerson to the State Department could also strengthen ties and bolster liberalism. Before becoming Secretary of State, Tillerson was the CEO of ExxonMobil, and the Director of Exxon Neftegas, a 
joint venture between ExxonMobil, Russia, Japan, and India. Tillerson organized deals with Rosneft to develop shale oil in Russia during 2011. He met with Putin and Igor Sechin, Rosneft's CEO and close friend of Putin, several times to develop a working relationship. Tillerson was awarded Russia's Order of Friendship for his oil deals in 2013. Recently, Trump's budget called for initiating energy development in the Arctic National Wildlife Refuge to strengthen America’s energy security (Office of Management and Budget 2018).

Trump/Tillerson and Putin/Russia share interests, and the likelihood of cooperation goes up when states have mutual interests. This interest is increasing business for ExxonMobil and Rosneft while increasing tax revenue for America and Russia. If the U.S. and Russia start to cooperate, a liberal framework would best explain the Arctic, as states would seek a stable region. The two states could forge ahead with oil deals and other joint ventures that eventually leads to low-level politics. A stable, conflict-free Arctic would allow industry and enterprise to flourish. From low-level politics, the states could work on high-level politics and eventually security and military issues. However, before a liberal framework can best explain the region, the U.S. would have to remove all sanctions from Russia and Russian officials. The removal of sanctions is unlikely to happen, even with Trump as president. The sanctions have opened the door for Chinese investment and cooperation.

Staun argues that Russia's Arctic power is more in line with a status quo power than a revisionist power. "Paradoxically, Russia has followed the rules of the game in the Arctic - while at the same time breaking the rules of the game in Ukraine" (Staun 2017 p. 314). Russia is a critical supporter of the AC and BEAR while strictly adhering to the 
Ilulissat Declaration and UNCLOS in the region without threatening Arctic neighbors (Staun 2017). Russia is not pursuing "the Soviet maximalist demands of past times" (Staun 2014 p. 323). If Russia seeks to be the regional hegemon, setting up a sphere of influence would increase their economic gains while having influence over regional organizations to legitimize Russia's foreign policy goals. Once either China or Russia is the regional hegemon, how long will the marriage of convenience last? If complex interdependence is strong enough the divorce is unlikely to happen allowing the region to remain stable.

However, not all forms of Arctic governance will be welcomed. Russia will oppose most forms of NATO and EU expansion as "encroachment into what they consider their traditional sphere of influence" (Flake 2017 p. 23). NATO stated they plan to increase search and rescue operations to ensure safe navigation while protecting territorial claims and providing energy security for Europe. Russia views NATO in the region as a threat to its interests because the West will try to internationalize the Northern Sea Route (Flake 2017). NATO’s Cold Response exercise worried Russia because they believed the drill was aimed at them. In the exercise, Norland, a large nondemocratic state, claimed an oil deposit within the territorial waters of Midland, a small democratic state. NATO then comes to the aid of Midland and helps win the war (Konyshev and Sergunin 2012)

Moscow believes NATO's new mission is securing resources around the globe (Konyshev and Sergunin 2014). Russia is opposed to an increase in these forms of governance and past western expansion to Georgia and Ukraine has led to conflict. Russia would most likely favor increasing NATO relations through expanding the 
Partnership for Peace, the Euro-Atlantic Partnership Council, and the NATO-Russia Council. Putin told Oliver Stone he considered the option of having Russia join NATO when Clinton was president (Russia Today 2017).

Despite Ukraine, in which sanctions stopped economic cooperation between Russia and the West, Arctic relations continued their normal path of cooperation. (Byers 2017). Some cooperation is due to states' interests, but complex interdependence explains the long-term cooperation, and how it can reduce tension during a crisis (Byers 2017). The Arctic has seen forum shopping before with the Arctic Five negotiating a fishing agreement rather than in the Arctic Council. However, if states in the future use different organizations to legitimize a policy because it is favorable to a certain policy or another could cause tension. Some states would argue they were left out, such as when China claimed the region as a global common or in the Arctic Five case.

Liberalism is increasing as states recognize indigenous groups. States are increasing the responsibility of regional organizations, private entities are investing in the region, and states believe they can't end the threat of climate change by themselves. However, liberalism can also produce conflict in the region. The growth of the EU and NATO will create tension, while it is possible that Russia and China will seek influence in regional governance structures that favor their interests, possibly creating a new regional order. Governance will continue to grow at all levels fostering stability and maybe creating tension while cooperation on environmental problems and search and rescue increases. Every state in the region will receive a relative gain for being included in Arctic governance; however, the gains won't be equal.

\section{Realism:}


One great power and a former superpower seek a sphere of influence, attempting to shift the regional and global balance of power away from the status quo causing clashes of interest. Lacking binding Arctic governance, the region is anarchic, leading states to struggle for power. Russia is strengthening itself to give rise to "opposition from the U.S. and its allies, who are seeking to retain their dominance" (Russian Federation 2015 p. 3). China and Russia want an Arctic that favors their balance of power by creating a new regional order, while the U.S. is an empire reluctant to cede its global hegemon. This will return the Arctic to a geopolitical arena for great power competition. "There is a growing concern that due to this situation the current era of high political stability of the Arctic may be lost" (Heininen 2017 p. 5).

States will try to take advantage of each other in the Arctic to ensure better gains based on the regional structure. Russia stated they want the Arctic based on international law because they have influence in smaller organizations. This helps Russia grow their political power in ways that won't challenge American power. Without strong, binding agreements and institutions, Arctic governance is explained by the regional structure that helps increase actors' power. "The IR-liberalist discourse is not inherently stable, even if it is rather institutionalized and sedimented and the IR-liberalist side can claim strong, economic interests in the region... However, concerns for national security could lessen the importance of these interests, thus undermining the stability of the IR-liberalist discourse" (Staun 2014 p. 328). Also, it appears that Russia would be willing to take military action if the regional order and international law don't favor their goals.

The current structure is based on the global balance of power, and how the U.S. is opposed to ceding power to organizations that might limit future actions. "It is the 
position of the United States that the Arctic Council should remain a high-level forum devoted to issues within its current mandate and not be transformed into a formal international organization particularly one with assessed contributions" (White House 2009 p. 4). The U.S. has limits on its regional cooperation, which "coincide at the point where regional interests and American interests diverge" (Sharp 2011 p.307). Due to America's unwillingness to increase Arctic governance, the region has two binding treaties, and the AC doesn't discuss military or security issues. There are no transit route agreements and territorial claims overlap. Once conflict happens, as shown when Canada pulled out of the AC over Ukraine, Arctic institutions won't be able to stop or change state behavior. A liberal framework will be unable to explain the region until a new regional/world order is established.

Russia will target places the West is reluctant to spend resources and manpower on while China seeks to expand their trade network via the One Belt, One Road initiative. China would have the relative gain advantage over every state if allowed to keep expanding in the Arctic. China invested $\$ 90$ billion (Grady 2018) and underwrote development for regional seaports, mining and energy companies, pipelines, and infrastructure such as airports, railways and roads in Russia, Iceland, Greenland, Finland, and Norway. Some of the Chinese regional expansion is under the Arctic component of the \$1 trillion One Belt, One Road initiative attempting to link Asia, Europe, and Africa along transport and logistics networks (Dillow 2018).

If the U.S. wants to keep their global hegemony, the U.S. will work to effectively impede Chinese gains in the region, creating economic and possibly military tension with China and Russia. Russia, currently, is unable to grow without Chinese assistance after 
years of a stagnate economy. If the U.S. is unable to impede China, both China and Russia would be able to increase their economies to grow their militaries while continuing to invest in the region. The U.S. seeks to maintain a favorable global balance of power, but this would harm America's security and economic interests in the region and around the globe (DOD 2018). If the U.S. remains uninterested in the Arctic, Russia and China would be able to create a regional order based on international law, and the realist explanatory framework would not be useful for the Arctic until and if the marriage of convenience ends.

Ten percent of the Arctic has multiple claims, leading states to compete for land, resources, and transit routes that could spark another conflict or impose on smaller powers as "Russia continues to seek to redraw international borders by force" (Chan 2017). Russia will also use UNCLOS since they believe they have both the law and evidence to legally claim about half of the Arctic seabed. Russia also has an interest in ensuring other states back UNCLOS to legitimatize the Russian EEZ (Staun 2014). The American need for freedom of seas, and not ratifying UNCLOS, signals the U.S. is more isolationist than others in the region (Sharp 2011). However, if UNCLOS rules the Lomonosov Ridge in favor of America, Canada, or Denmark, the resource-rich area could spark a regional conflict.

However, China also seeks to protect its international rights in the Arctic and will safeguard against any infringement of those rights and protect the common interest of all states (PRC 2018). China believes the Arctic will be carved up by western powers and exclude everyone else. 
Russia will seek opportunities to control territory in the Arctic much like they have in the past with Ukraine and Georgia. Russia will go after small and slow accumulation of power in areas that won't trigger a casus belli response by America or NATO, in what Russia calls "an open, rational, and pragmatic foreign policy ruling out costly confrontation" (Russian Federation 2015 p. 6). The failure by the West to respond to Russian policies in Ukraine encourages Russian aggression in the region (Krickovic 2015).

Russia claims the Northern Sea Route as internal waters, thus giving them jurisdiction to protect Chinese shipping vessels, while the U.S. seeks to preserve all rights and freedoms of the sea and airspace. "The Arctic is key strategic terrain. Russia is taking aggressive steps to increase its presence there," stated Secretary of Defense Mattis (Gramer 2017). China seeks secure transit routes to expand a global trade network around sixty countries that will rival the American centered trade agreements. Allowing Russian sovereignty over the area permits Russia and China to foster economic development in the Arctic through the Polar Silk Road. The Arctic economic network is a piece of the Chinese plan to shift the global economy to its favor, and there might be tension if NATO or the U.S. tries to impede their Arctic economic growth. Wright argued whoever controls the Arctic transit routes will control the world economy, which will benefit revisionist states like Russia and China (Wright 2011).

Krasner argues that governments must protect certain industries in the interest of their national security. The U.S. grand strategy is to prevent any single state from controlling more raw resources than America controls. "Just as economic interests would induce government to intervene on behalf of business, alleged business interests would be 
used by governments as a pretext for power politics" (Herz 1950 p. 176). For both Russia and the United States, oil is a pillar of their economy and accounts for most of Russia's tax money. Russia will be able to develop resources to grow their economy and strengthen their military while providing transit security for China in the open Arctic. While Russia is weaker, the U.S. should limit Russia's Arctic development, try to stagnant their economy through sanctions, and limit Russian trade. The sanctions against Russia by the U.S., the EU and Norway target security and energy projects in the Arctic and should expand if necessary (Luszczuk 2017). The U.S. can take the moral position while maintaining their military force by sanctioning and impeding the Russian economy. However, new or renewed sanctions might be considered a "declaration of war" by some Russians (Turak 2018).

While the U.S. has the defensive advantage around the globe, Russia currently has the offensive and defensive advantage in the Arctic. Russia will work to secure areas that won't trigger a nuclear showdown with the West, much like Russia has in the past with Ukraine and Georgia. Russia has an incentive to use military force to increase power since they have the regional offensive advantage. Jervis argues this is when most wars happen. If Russia uses their regional military advantage to further their goals because Russian interests were not secured through regional organizations and international law, it would allow for a better realist explanation of the region.

The American Arctic defensive capabilities consist of two icebreakers, two bases, three airfields, and forty-one nuclear submarines capable of surfacing from under ice. With the exception of the submarines, U.S. forces lag behind Russian Arctic capabilities. The U.S. also lacks an Arctic deep-water port. However, the 2018 defense budget 
authorized six new icebreakers with the first one expected in 2023. Russia has forty-one icebreakers with eleven under construction, three bases, eighteen airfields, nine navy bases, and twenty-five submarines capable of surfacing from under the ice. The U.S. Navy and Air Force far outnumber the Russian counterparts, but the U.S. doesn't have equipment suitable for the harsh conditions, giving Russia the regional advantage (Russian Federation 2015). Even without conflict, this regional advantage gives Russia security leverage, which China will find useful to protect their Polar Silk Road. Putin stated, "This region has traditionally been a sphere of our special interest" (Putin 2014). Russia and China have the perfect opportunity to exploit American overreach because the U.S. is wary of spending too much time and effort in the Arctic region when there are other, more pressing security risks around the globe (DOD 2010).

The U.S. Navy is ready to protect the national interests and prevent conflict in the region either independently or in conjunction with other states (U.S. Navy 2014 and White House 2009). America seeks peaceful resolutions of disputes but will use force when necessary. Russia is prepared to use its military if its interests are threatened (Russian Federation 2015). The DOD is committed to invest and improve American forces to deter aggression in the Arctic (DOD 2016). The DOD is cautious because "being too aggressive in taking steps to address anticipated future security risks may create the conditions of mistrust and miscommunication under which such risks could materialize" (DOD 2010 p. 13). If the U.S. conducts an Arctic military build-up, this opens the possibility for a regional arms race as Russia might feel threatened by the increased American capabilities. Thus, the security dilemma starts to spiral as each side seeks to increase their military capabilities but do not actually increase their security. 
Russia is against any ballistic missile defense system operating in the Arctic and is working to match any American capabilities. Atland describes this as "action-reaction dynamics" that may lead to an unintended security dilemma increase. Part of the communication problem is Arctic states don't have a forum to discuss security issues (Atland 2014), and Russia and NATO members lack trust in each other. The security dilemma will spiral if the U.S. pivots to the region, however, the Arctic is not the focus of U.S. foreign policy, keeping the chance of a security dilemma low.

NATO currently doesn't have a large role in the region. However, based on de Hoop Scheffer, when the Arctic melts, NATO will protect energy sources and territory while providing search and recsue services. NATO does not want conflict but will not tolerate Russian violations of international law. Russia is already wary of NATO expansion, and most forms of NATO Arctic enlargement will trigger a Russian reaction. After being invaded numerous times, Russia seeks natural barriers to buffer any future Napoleons or Hitlers. Sharp argues NATO will take a secondary role in the Arctic, "based on the conclusion that a more direct role in Arctic security will be met with Russian resistance," which will decrease security (Sharp 2011 p. 314).

Tillerson reaffirmed the U.S. commitment to Europe and to ending the Ukrainian crisis before he was fired. The crisis "made clear how energy supplies can be wielded as a political weapon. Enhancing European energy security by ensuring access to affordable, reliable, diverse, and secure supplies of energy is fundamental to national security objectives" (Tillerson 2017). The U.S. will work to ensure no state can extort energy from the EU. Tillerson stated the U.S. seeks positive relations with Russia, "however, 
Russia has shown it seeks to define a new post-Soviet global balance of power, one in which Russia...seeks to impose its will on others by force" (Tillerson 2017).

With China, Russia and the U.S. staking claims in the Arctic, it appears the region will transform from a bipolar Arctic to a multipolar Arctic. The U.S. has the better global force, but Russia argues they have a regional advantage due to the amount of Russian Arctic coast and their militarization. Since China and Russia view each other as strategic partners and have plans for the Polar Silk Road, a potential power imbalance will leave the U.S. as the odd state out. Most wars break out when there is a lopsided balance of power.

"With three great powers - the U.S. Russia and China - involved in the region, we may soon experience a clash of security cultures from cooperative security to a strategy of primacy or great power competition" (Lamy 2017 p. 96). Other states such as Iceland, India, and Japan believe the Arctic will become a point of tension over great power's interests as well. With the lack of a higher authority, states will eventually go to war over differences in their interests. The weaker states within the Arctic have either already bandwagoned with the U.S. under NATO or are attempting to pass the buck by having good diplomatic relations with both Russia and the U.S. The three great powers in the system will seek to maximize their power in the region but won't seek a global hegemon since triggering a total war would limit each powers' chance of survival. Realism is based on survival, both Russia and China seek an appropriate amount of power for either their own Arctic or Eurasian spheres of influence that will increase their chance of survival. 
Currently, it seems like liberalism would best describe Arctic international relations. This is because regional governance based on mutual interests increased significantly since the end of the Cold War. However, the stakes were low since development was near impossible and extremely costly. Also, regional governance tends to either be the focus of Russia or the U.S., while leaving the other great power outside the governance structure. Second, some states don't want Arctic governance to focus on security issues because they do not want to limit their sovereignty in the region. The U.S. seeks to contain any regional governance that might infringe on their actions and is against any transformation of the Arctic Council's mandate. Third, the U.S. and Russia will most likely not be able to solve the "easy disputes" of Syria, Ukraine, and border issues. Forth, the U.S. is unlikely to end sanctions on Russia, further impeding any Arctic cooperation between the two states. Finally, the Arctic has no framework or lacks a strong enough collective security to stop a large power from partaking in unilateral action when its interests are challenged. These reasons are why a liberal framework will be unable to explain the region. Arctic states will assume the worst-case scenarios that don't necessarily reflect current international relations because they are uncertain of each other's intentions, and "choose to play it safe" (Atland 2014 p.152).

Arctic development is becoming cheaper and the focus of Russian foreign policy. Russia and the U.S. stated they are willing to use force when necessary to defend their interests outside of any Arctic governance. UNCLOS is a recognized framework for sovereignty disputes, but the legal and technical ambiguities are an insufficient mechanism for dispute resolution. States will need goodwill and a forum, such as the AC, to mitigate issues (Sharp 2011). When interests clash between Russia, China, and the 
U.S., tensions will rise. It appears realism will offer a better explanation since great powers will ignore Arctic norms and international laws based on liberal theory.

Russian northern forces atrophied before Putin sought a sphere of influence in 2008, while the U.S. has been reluctant to focus on the Arctic because they have other issues around the globe. This gives Russia a regional advantage over any Western military. However, the DOD committed to invest and improve American forces to deter aggression in the Arctic (DOD 2016). Putin and Russia will negatively view any U.S. or NATO militarization of the region, possibly triggering an arms race. The DOD cautions against spending too much time, money and effort in the region with other, high threat risks and austerity (DOD 2010), possibly allowing the U.S. to escape from the security dilemma. However, this leads the U.S. to underestimate Putin's desire for a sphere of influence.

Another possibility is Russia will argue they are protecting Russian minorities to occupy areas that don't trigger a NATO reaction. With various agreements and claims on Arctic territory, Russia might try to annex a NATO member's territorial claim. Depending on the reaction by NATO members to invoke Arctic Five, which without any deaths, the slow decision-making structure with the lack of political will and defense expenditure cuts, leaves NATO members to most likely debate the issue without any action (Eyal 2014). “As presently postured, NATO cannot successfully defend the territory of its most exposed members" (Shlapak and Johnson 2016 p. 6). This gives Russia an incentive to increase their size while being able to use Peter the Great and Soviet historical claims of returning Russia to superpower imperial status. 
Shlapak and Johnson, and NATO General Shirreff argued Russia can ignore the norms of territorial aggression due to inadequate NATO defense (Shirreff 2016). If Russia claimed territory in either the Baltic or the Arctic, Moscow would quickly annex the land into the Russian Federation. NATO would either have to accept the occupation or launch a counter-offensive that might develop into a nuclear war, both bad options for the West (Shlapak and Johnson 2016). If the U.S. accepted occupation, a new Russian sphere of influence would be created and another Berlin-like wall or ship patrols would possibly be used to fortify the new border. This would legitimize the new Russian regional order. Depending on whether or not the collective defense agreement failed to protect another member's sovereignty, this could allow Russia to sow seeds to undermine NATO. However, like other Russian Arctic regulations, the U.S. will probably reject any new claims, arguing Russia is acting beyond its territorial waters. The U.S. in NSPD-66 ensured the freedom of navigation and U.S. interests in the Northern Sea Route (U.S. Navy 2014). The U.S. may exercise their sovereign rights in the Arctic to protect natural resources since energy is a national interest (White House 2009). This worries Russia, as they are concerned an ice-free Arctic will allow Western warships with missile systems to travel into their EEZ (Russian Federation 2015). However, Russia argues they have the localization dominance due to their coastline, icebreaker fleet and military strength in the region.

Since the end of World War II, states have either jockeyed for power and position within various international organizations or tried to limit the expansion of those organizations to ensure more unilateral actions if necessary. States will use international organizations like UNCLOS and Arctic Five to try to legally exclude other states from 
developing resources while ensuring their future economy won't be impeded by regulations or other states. Once Russia establishes a boundary and favorable regional governance, they will secure the area to protect Chinese trade.

Realism will best describe Arctic relations when development costs become cheaper and transit safer due to the lack of ice. "The tectonic shifts that are happening are the rise of a powerful China... and the resurgence of a weak, but very dangerous, and well-armed Russia, so the return of a period of great power competition is happening" (Flournoy 2017). Also, the U.S. is "guided by a return to principled realism" (White House 2017). The risk of interstate war is increasing, and the Arctic is not immune to energy security and geopolitics (Coats 2018).

Russia and China seek to be the regional hegemon or create a sphere of influence since projecting force across the world is costly and hard. Under the One Belt, One Road initiative, China seeks to establish a trade block with sixty states, while hoping to shift the global economy to its favor, thus altering the global balance of power. China will seek safe Polar Silk Road routes protected by Russian forces. Once states have an Arctic sphere, states will protect their interests through proxy wars, international legal action, and economic competition creating Cold War 2.0. America can either allow the new Polar Silk Road and a shift in the balance of power or seek to stymie the progress through sanctions/force. There will always be security competition, and it will be intense at times when states seek either regional or global hegemony. 


\section{Chapter 6:}

\section{Conclusion:}

Currently, it seems like liberalism would best describe Arctic international relations. This is because regional governance based on mutual interests increased significantly since the end of the Cold War. However, the stakes were low since development was near impossible and extremely costly. Also, regional governance tends to either focus on Russia or the U.S., while leaving the other great power outside the governance structure. Second, some states don’t want Arctic governance to focus on security issues because they do not want to limit their sovereignty in the region. The U.S. seeks to contain any regional governance that might infringe on their actions and is against any transformation of the Arctic Council's mandate. Third, the U.S. and Russia will most likely not be able to solve the "easy disputes" of Syria, Ukraine, and border issues. Fourth, the U.S. is unlikely to end sanctions on Russia, further impeding any Arctic cooperation between the two states. Finally, the Arctic has no framework or lacks a strong enough collective security to stop a large power from partaking in unilateral action when its interests are challenged. These reasons are why a liberal framework will be unable to explain the region. Arctic states will assume the worst-case scenarios that don't necessarily reflect current international relations because they are uncertain of each other's intentions, and "choose to play it safe" (Atland 2014 p.152).

Arctic development is becoming cheaper and the main driver of Russian interests (Laruelle 2014). Every state publicly stated the need for diplomacy and international law, although Russia and the U.S. stated they are willing to use force when necessary. It appears when the regional order or international law doesn't favor Russia, they will use 
their regional military advantage to defend their interests (Staun 2017). The region's lack of governance structure won't stop great powers under the anarchic system. The United Nations Security Council will also be unable to stop a conflict, as China, Russia, and the U.S. each hold veto power, and would block any resolution. When interests clash between Russia, China, and the U.S., tensions will rise, and it appears realism will offer a better explanation since great powers will ignore Arctic norms and international laws. However, states will avoid a total nuclear war since MAD threatens the survival of the state.

Russian northern forces atrophied before Putin sought a sphere of influence in 2008, while the U.S. has been reluctant to focus on the Arctic because they have other issues around the globe. This gives Russia a regional advantage over any Western military. However, the DOD committed to invest and improve American forces to deter aggression in the Arctic (DOD 2016). Putin and Russia will negatively view any U.S. or NATO militarization of the region, possibly triggering an arms race. However, the DOD cautions against spending too much time, money and effort in the region with other, high threat risks and austerity (DOD 2010). This could allow the U.S. to escape from the security dilemma, but possibly underestimate Putin's desire for a sphere of influence. The U.S. cedes regional hegemon status to Russia and China, allowing the two states to forge a new regional order that resembles the Silk Road, thus returning the world to two economic blocks. As Cold War 2.0 gets underway, militaries will posture, and proxies might fight, but due to nuclear weapons, neither bloc will directly confront each other. Under a new order, China and Russia will keep the region stable to increase economic 
investment and opportunities, while China seeks to become the global economic juggernaut via the Silk Road.

Another possibility is Russia will argue they are protecting Russian minorities to occupy areas that don't trigger a NATO reaction. With various agreements and claims on Arctic territory, Russia might try to occupy a NATO member's territorial claim like Denmark's. Without any deaths, NATO is unlikely to invoke Article Five because of its slow decision-making structure and defense cuts, leaving members to most likely debate the issue without any action (Eyal 2014). “As presently postured, NATO cannot successfully defend the territory of its most exposed members" (Shlapak and Johnson 2016 p. 6). This gives Russia an incentive to increase the size of their economic bloc while being able to use Peter the Great and Soviet historical claims of returning Russia to superpower imperial status.

Russia can ignore the norms of territorial aggression due to inadequate NATO defense and their regional offensive advantage (Shirreff 2016). If Russia claimed territory in either the Baltic or the Arctic, Moscow would quickly work to annex that land to make it part of the Russian Federation. NATO would either have to accept the occupation or launch a counter-offensive that might develop into a nuclear war, both bad options for the West (Shlapak and Johnson 2016). If the U.S. accepted occupation, a new Russian sphere of influence would be created and another Berlin-like wall or ship patrols potentially would fortify the new border. Depending on whether the collective defense agreement failed to protect another member's sovereignty, this would allow Russia to sow seeds to undermine NATO. However, like other Russian Arctic regulations, the U.S. will probably reject any new claims, arguing Russia is acting beyond its territorial waters. The U.S. 
argued in NSPD-66 the Navy can protect the freedom of navigation and U.S. interests in the Northern Sea Route (U.S. Navy 2014). The U.S. may exercise their sovereign rights in the Arctic to protect natural resources since energy is a national interest (White House 2009). This worries Russia, as they are concerned an ice-free Arctic will allow Western warships with missile systems to travel into their EEZ (Russian Federation 2015). However, Russia has argued they have the localization dominance due to their coastline, icebreaker fleet and military strength in the region. The U.S. doesn't have any plans to match Russia’s regional dominance preventing a security dilemma.

Since the end of World War II, states have either jockeyed for power and position within various international organizations or tried to limit the expansion of those organizations to ensure more unilateral actions if necessary. States will use international organizations like UNCLOS and Arctic Five to try to legally exclude other states from developing resources while ensuring their future economy won't be impeded by regulations or other states. Once Russia establishes a boundary and favorable regional governance, they will secure the area to protect Chinese trade. Whenever a new regional order is established, the marriage of convenience might end as both Russia and China seek to become the regional economic hegemon, causing tension between the two neighboring states. However, complex interdependence in the Arctic might keep the two states from using military force as they would hurt the Polar Silk Road economic development.

Realism will become the best theory to describe Arctic relations when development costs become cheaper and transit safer due to the lack of ice. "The tectonic shifts that are happening are the rise of a powerful China... and the resurgence of a weak, 
but very dangerous, and well-armed Russia, so the return of a period of great power competition is happening" (Flournoy 2017). Also, the U.S. is "guided by a return to principled realism" (White House 2017). The risk of interstate war is increasing, and the Arctic is not immune to energy security and geopolitics (Coats 2018).

Russia and China will seek to be the regional hegemon or create a sphere of influence since projecting force across the world is costly and hard. Under the One Belt, One Road initiative, China seeks to establish a trade block with sixty states, while hoping to shift the global economy to its favor, thus altering the global balance of power. China seeks safe Polar Silk Road routes protected by Russian forces. Once states have an Arctic regional sphere that suits them, states will protect their interests by any means necessary. The United States can either allow the new Polar Silk Road and a shift in the balance of power or seek to stymie the progress through sanctions/force. There will always be security competition, and it will be intense at times when states seek either regional or global hegemony. 


\section{Works Cited:}

Abbott, Kenneth W., and Snidal Duncan. "Why States Act through Formal International Organizations.” Journal of Conflict Resolution 42, no.1 (1998): 3-32.

Abbott, Kenneth W., and Snidal Duncan. "Hard and Soft Law in International Governance." International Organization 54, no. 3 (2000): 421-456.

Action Plan to Eliminate Pollution of the Arctic. Signed June 2001. https://oaarchive.arctic-council.org/bitstream/handle/11374/459/ACSAOFI01_8_ACAP_2001.pdf?sequence=1 HYPERLINK "https://oaarchive.arcticcouncil.org/bitstream/handle/11374/459/ACSAOFI01_8_ACAP_2001.pdf?sequence=1\&isAllowed=y"\& HYPERLINK "https://oaarchive.arctic-council.org/bitstream/handle/11374/459/ACSAOFI01_8_ACAP_2001.pdf?sequence=1\&isAllowed=y"isAllowed=y.

Agreement on Cooperation on Marine Oil Pollution Preparedness and Response in the Arctic. Signed May 15, 2014. https://www.state.gov/documents/organization/264791.pdf.

Aizhu, Chen, Josephine Mason, and Pei Li. "Russia remains China's top oil supplier as pipeline expands.” Reuters. February 24, 2018. Accessed February 25, 2018. https://www.reuters.com/article/us-china-economy-trade-crude/russia-remainschinas-top-oil-supplier-as-pipeline-expands-idUSKCN1G808M.

Alexeeva, Olga V., and Frederic Lasserre. "The Snow Dragon: China's Strategies in the Arctic.” China Perspectives (2012/3): 61-68.

Ali, Idrees. "U.S. military puts 'great power competition' at heart of strategy: Mattis." Reuters. January 19, 2018. Accessed February 2, 2018. https://uk.reuters.com/article/uk-usa-military-china-russia/u-s-military-puts-greatpower-competition-at-heart-of-strategy-mattis-idUKKBN1F820H.

American Bureau of Shipping. "Navigating the Northern Sea Routes: Status and Guidance Advisory Guide." American Bureau of Shipping, 2014. Accessed November 14, 2017. https://ww2.eagle.org/content/dam/eagle/publications/2014/NSR_Advisory.pdf.

Arctic Search and Rescue Agreement. Signed May 2011. http://www.ifrc.org/docs/idrl/N813EN.pdf.

Arctic Institute. "Countries.” The Arctic Institute. April 4, 2017. Accessed August 2, 2017. http://www.thearcticinstitute.org/countries/. 
Atland, Kristian. "Interstate Relations in the Arctic: An Emerging Security Dilemma?." Comparative Strategy 33 (2014): 145-166.

Axelrod, Robert. The Evolution of Cooperation. New York: Basic Books, 1984.

Axelrod, Robert and Robert O. Keohane. "Achieving Cooperation under Anarchy: Strategies and Institutions.” World Politics 38 (1985): 226-254.

Bailes, Alyson JK; and Olafsson, Kristmundur. "Nordic and Arctic Affairs: Iceland's National Security Policy: Latest Progress.” Center for Small State Studies (2014): $1-3$.

Bailey, Kevin M. "An Empty Donut Hole: The Great Collapse of a North American Fishery." Econology and Society 16, no. 2 (2011): 1-13.

Baker, Peter; and Sophia Kishkivsky. "Trump Signs Russian Sanctions into Law, With Caveats." New York Times, August 2, 2017. Accessed August 17, 2017. https://www.nytimes.com/2017/08/02/world/europe/trump-russia-sanctions.html.

Barents Euro-Arctic Cooperation. "Cooperation in the Barents Euro-Arctic Region." Barents Euro-Arctic Cooperation. Accessed June 7, 2017. http://www.barentscooperation.org/en/About.

Biden, Joseph, Jr., and Michael Carpenter. "How to Stand up to the Kremlin: Defending Democracy Against its Enemy.” Foreign Affairs, January/February 2018.

Blank, Stephen. “China's Arctic Strategy.” The Diplomat, June 20, 2013. Accessed July 21, 2017. http://thediplomat.com/2013/06/chinas-arctic-strategy/.

Butterfield, Herbert. History and Human Relations. New York: Macmillan \& Co, 1951.

Byers, Michael. "Crises and international cooperation: An Arctic case study." International Relations 31, no. 4 (2017): 375-402.

Canada Department of Foreign Affairs and International Trade. "Statement on Canada's Arctic Foreign Policy: Exercising: Sovereignty and Promoting Canada's Northern Strategy Abroad.” August 20, 2010. http://www.international.gc.ca/arcticarctique/assets/pdfs/canada_arctic_foreign_policy-eng.pdf.

Canada Office of the Prime Minister. "Prime Minister Announces Expansion of Canadian Forces Facilities and Operations in the Arctic.”. August 10, 2007. http://pm.gc.ca/eng/media.asp?id=1787. 
Carr, E. H. The Twenty Years' Crisis 1919-1939: An Introduction to the Study of International Relations. London: Macmillan \& Co, 1946.

Carrington, Damian. "Melting Arctic ice cap falls to well below average." The Guardian, September 20, 2017. Accessed September 20, 2017.

https://www.theguardian.com/environment/2017/sep/20/melting-arctic-ice-capfalls-to-well-below-average.

Chan, Sewell. "Mike Pence, in Montenegro, Assures Balkans of U.S. Support". New York Times, August 2, 2017. Accessed August 5, 2017.

https://www.nytimes.com/2017/08/02/world/europe/pence-montenegro-markovicnato.html?ref=topics.

Checkel, Jeffrey T. "Review: The Constructivist Turn in International Relations Theory." World Politics. 50, no. 2 (1998): 324-348.

Cheong, Serene. "Makes Crude Costlier for Europe.” Bloomberg Markets, January 2, 2018. Accessed January 5, 2018. https://www.bloomberg.com/news/articles/201801-02/russia-s-oil-friendship-with-china-makes-crude-costly-for-europe.

Director of National Intelligence. Worldwide Threat Assessment of the US Intelligence Community, by Daniel R. Coats. https://www.dni.gov/files/documents/Newsroom/Testimonies/2018-ATA--Unclassified-SSCI.pdf.

Conley, Heather. "The colder war: U.S., Russia and others are vying for control of Santa's Back Yard." Washington Post, December 23, 2011. Accessed June 6, 2017. https://www.washingtonpost.com/opinions/the-colder-war-us-russia-andothers-are-vying-for-control-of-santas-backyard/2011/12/20/gIQAWBc7DP_story.html?noredirect=on\&utm_term=.cc4fcc0d $8 \mathrm{~d} 97$.

Council of the European Union. "Council conclusions on Arctic issues." Brussels, Belgium. December 8, 2009.

https://ec.europa.eu/maritimeaffairs/sites/maritimeaffairs/files/docs/body/arctic_c ouncil_conclusions_09_en.pdf.

De Hoop Scheffer, Jaap. "Security Prospects in the High North." Speech, Reykjavik, Iceland, January 29, 2009. http://www.nato.int/docu/speech/2009/s090129a.html.

De Luce, Dan. "If Russia Started a War in the Baltics, NATO would lose-Quickly." Foreign Policy, February 3, 2016. Accessed June 17, 2017. http://foreignpolicy.com/2016/02/03/if-russia-started-a-war-in-the-baltics-natowould-lose-quickly/. 
Denmark's Ministry of Foreign Affairs. Danish Diplomacy and Defense in the Times of Change. Copenhagen, Denmark: May 2016. http://um.dk/en/foreignpolicy/danish-defence-and-diplomacy-in-times-of-change/.

Denmark's Ministry of Foreign Affairs. Denmark, Greenland and the Faroe Islands: Kingdom of Denmark Strategy for the Arctic 2011-2020. Copenhagen, Denmark: August 2011.

Department of Defense (DOD). Report to Congress on Arctic Operations and the Northwest Passage. Washington, DC: OUSD (Policy), May 2011. http://www.defense.gov/pubs/pdfs/Tab_A_Arctic_Report_Public.pdf.

Department of Defense. Arctic Strategy. Washington, DC: Secretary of Defense. 2013. http://www.defense.gov/pubs/2013_Arctic_Strategy.pdf.

Department of Defense. Quadrennial Defense Review 2014. Washington, DC: Secretary of Defense. 2014 http://www.defense.gov/pubs/2014_Quadrennial_Defense_Review.pdf.

Department of Defense. Report to Congress on Strategy to Protect United States National Security Interests in the Arctic Region. Washington, DC: December 2016. https://www.defense.gov/Portals/1/Documents/pubs/2016-Arctic-StrategyUNCLAS-cleared-for-release.pdf.

Department of Defense. Summary of the 2018 National Defense Strategy of The United States of America: Sharpening the American Military's Completive Edge. Washington, DC: 2018. https://www.defense.gov/Portals/1/Documents/pubs/2018-National-DefenseStrategy-Summary.pdf.

Department of National Defense (DND). Arctic capabilities study. Ottawa, Canada: Director General Strategic Planning. June 2000.

Department of National Defense. Arctic Integrating Concept. Ottawa, Canada: Chief of Force Development National Defense Headquarters. 2010.

Department of State. Treaty Between the United States of America and the Russian Federation on Measures for the Further Reduction and Limitation of Strategic offensive Arms. Prague, Czech Republic: 2011. https://www.state.gov/documents/organization/140035.pdf.

Dillow, Clay. "Russia and China vie to beat the US in the trillion-dollar race to control the Arctic." $C N B C$, February 6, 2018. Accessed February 6, 2018. https://www.cnbc.com/2018/02/06/russia-and-china-battle-us-in-race-to-controlarctic.html. 
Dolata, Petra. "A New Canada in the Arctic? Arctic Policies under Harper." Canadian Studies78 (2015): 131-154.

Donilon, Tom. Interview with Tom Donilon and Michael Morell. Intelligence Matters. Podcast audio. October 3, 2017. https://traffic.libsyn.com/secure/forcecdn/highwinds/intelligencematters/Final_IM_Donilon_.mp3

Ebinger, Charles K.; Zambetakis, Evie. "The Geopolitics of Arctic melt." International Affairs 85, no. 6 (2009): 1215-1232.

Economist. "Western firms are coining it along China's One Belt, One Road." The Economist, August 3, 2017, Accessed December 10, 2017. https://www.economist.com/news/business/21725810-general-electric-got-23bnorders-infrastructure-project-last-year-western-firms.

Economy, Elizabeth. "Beijing's Arctic Play: Just the Tip of the Iceberg." Council on Foreign Relations, April 4, 2014, Accessed July 21, 2017. https://www.cfr.org/blog-post/beijings-arctic-play-just-tip-iceberg

European Commission. Report on the Implementation of the European Security StrategyProviding Security in a Changing World. Brussels, Belgium: December 11, 2008. https://www.consilium.europa.eu/uedocs/cms_data/docs/pressdata/en/reports/104 630.pdf.

European Commission. Joint Communication to the European Parliament and the Council. Brussels, Belgium: June 21, 2016.

http://www.eeas.europa.eu/archives/docs/arctic_region/docs/160427_jointcommunication-an-integrated-european-union-policy-for-the-arctic_en.pdf.

European Commission. The EU engages in the third round of negotiations to prevent unregulated fishing in the Arctic high seas. 2016.

https://ec.europa.eu/fisheries/eu-engages-third-round-negotiations-preventunregulated-fishing-arctic-high-seas_en.

European Council High Representative and the European Commission. Climate Change and International Security. Brussels, Belgium: 2008. http://www.consilium.europa.eu/ueDocs/cms_Data/docs/pressdata/EN/reports/99 387.pdf.

European Parliament. Resolution of 9 October 2008 on Arctic governance. Brussels, Belgium: 2008. http://www.europarl.europa.eu/sides/getDoc.do?type=TA\&language=EN\&referen ce=P6-TA-2008-474. 
European Parliament. Resolution of 20 January 2011 on a sustainable EU policy for the High North. Brussels, Belgium: January 20, 2011.

http://www.europarl.europa.eu/sides/getDoc.do?pubRef=-//EP//TEXT+TA+P7TA-2011-0024+0+DOC+XML+V0//EN.

European Parliament. Resolution of 12 March 2014 on the EU strategy for the Arctic. Brussels, Belgium. March 12, 2014. http://www.europarl.europa.eu/sides/getDoc.do?pubRef=//EP//NONSGML+TA+P7-TA-2014-0236+0+DOC+PDF+V0//EN.

European Parliament and the Council. The European Union and the Arctic Region. Brussels, Belgium, November 20, 2008. http://www.eeas.europa.eu/archives/docs/arctic_region/docs/com_08_763_en.pdf.

Evans, Tony and Wilson, Peter. "Regime Theory and the English School of International Relations: A Comparison.” Millennium: Journal of International Studies 21, no. 3 (1992): 330-352.

"Executive Order 13689 of January 21, 2015, Enhancing Coordination of National Efforts in the Arctic." Code of Federal Regulations, (2015): 4189-4194. https://www.federalregister.gov/documents/2015/01/26/2015-01522/enhancingcoordination-of-national-efforts-in-the-arctic.

Exner-Pirot, Heather. "Defense diplomacy in the Arctic: the search and rescue agreement as a confidence builder." Canadian Foreign Policy Journal 18, no. 2 (2012): 195207.

Eyal, Jonathan. "The Real Problems with NATO: What Trump gets Right, and Wrong." Foreign Affairs, March 2, 2017. Accessed March 10, 2017. https://www.foreignaffairs.com/articles/europe/2017-03-02/real-problems-nato.

Finland. Finland's Strategy for the Arctic Region. Helsinki, Finland: 2010.

Finland. Finland's Strategy for the Arctic Region 2013. Helsinki, Finland: 2013.

Finland's Prime Minister's Office. Government Policy Regarding the Priorities in the Updated Arctic Strategy. Helsinki, Finland: 2016.

Finnemore, Martha, and Kathryn Sikkink. "International Norm Dynamics and Political Change.” International Organization 54, no. 4 (1998): 887-917.

Flake, Lincoln. "Contextualizing and Disarming Russia's Arctic Security Posture." The Journal of Slavic Military Studies 31, no. 1. (2017): 17-29. 
Flournoy, Michele. Interview with Michele Flournoy and Michael Morell. Intelligence Matters. Podcast audio. October 26, 2017. https://raffic.libsyn.com/secure/forcecdn/highwinds/intelligencematters/IM_with_Flournoy_.mp3.

Gavrilov, Viatcheslav V. "Legal Status of the Northern Sea Route and Legislation of the Russian Federation: A Note." Ocean Development \& International Law 46, no. 3 (2015): 256-263.

Golubkova, Katya, Christian Lowe, and Giles Elgood. "Russian Finance ministry readies for fight with big oil over tax." Reuters, January 29, 2016. Accessed March 10, 2017. https://www.reuters.com/article/russia-oil-taxes/russian-finance-ministryreadies-for-fight-with-big-oil-over-tax-idUSL8N15C3Z1.

Gorbachev, Mikhail. "Speech in Murmansk at the ceremonial meeting on the occasion of the presentation of the Order of Lenin and the Gold Star Medal to the city of Murmansk.” Speech, Murmansk, Russia, October 1, 1987. https://www.barentsinfo.fi/docs/Gorbachev_speech.pdf.

Gourevitch, Peter Alexis. "The Governance Problem in International Relations." In Strategic Choice and International Relations, 127-164. Princeton: Princeton University Press, 1999.

Gramer, Robbie. "Here's what Russia's Military Build-up in the Arctic Looks like." Foreign Policy, January 25, 2017. Accessed December 5, 2017. http://foreignpolicy.com/2017/01/25/heres-what-russias-military-build-up-in-thearctic-looks-like-trump-oil-military-high-north-infographic-map/.

Grady, John. "Panel: China Investing in Infrastructure near the Arctic." USNI News, April 27, 2018. Accessed April 28, 2018. https://news.usni.org/2018/04/27/panelchina-investing-infrastructure-near-arctic.

Gratz, Jonas. "The Arctic: Thaw with Conflict Potential.” CSS Analysis in Security Policy 118 (2012): 1-4.

Grieco, Joseph M. "Anarchy and the Limits of Cooperation." International Cooperation 42, no. 3 (1988): 485-507.

Guschin, Arthur. "China, Iceland and the Arctic: Iceland is playing a growing role in China’s Arctic strategy." The Diplomat, May 20, 2015. Accessed June 10, 2017. http://thediplomat.com/2015/05/china-iceland-and-the-arctic/.

Haftendorn, Helga. "NATO and the Arctic: is the Atlantic alliance a Cold War Relic in a Peaceful Region now faced with non-military challenges?.” European Security 20, no. 3 (2011): 337-361. 
Halliday, Fred. The Middle East in International Relations: Power, Politics and Ideology. Cambridge: The University Press of Cambridge, 2005.

Harper, Stephen. "Harper Stands Up for Arctic Sovereignty.” Speech Ottawa, Canada, December 22, 2005.

https://cmss.ucalgary.ca/sites/cmss.ucalgary.ca/files/dcass6.pdf.

Heininen, Lassi. "High Arctic Stability as an Asset for Storm of International Politics- an Introduction." In Future Security of the Global Arctic: State Policy, Economic Security and Climate, edited by Lassi Heininen, 1-11. London: Palgrave Macmillan, 2017.

Heininen, Lassi. "Redefined Northern Security-a challenge to Arctic geopolitics?." Powerpoint Presentation at the Northern Research Forum, Girdwood, AK, October 2013.

Heininen, Lassi, Alexander Sergunin, and Gleb Yarovov. Russian Strategies in the Arctic: Avoiding a New Cold War. Moscow: Valdai Discussion Club, 2014. Accessed April 20, 2017.

http://valdaiclub.com/a/reports/russian_strategies_in_the_arctic_avoiding_a_new _cold_war/.

Herszenhorn, David M. "Russia Warns Denmark on Joining NATO Missile Defense." New York Times, March 22, 2015. Accessed April 20, 2017.

https://www.nytimes.com/2015/03/23/world/europe/russian-warns-denmark-onjoining-nato-missile-defense.html.

Herz, John H. "Idealist Internationalism and the Security Dilemma." World Politics 2, no. 2 (1950):157-180.

Herz, John H. Political Realism and Political Idealism: A study in Theories and Realities. Chicago: The University of Chicago Press, 1951.

Honneland, Geir. "Identity Formation in the Barents Euro-Arctic Region." Cooperation and Conflict 33, no. 3 (1998) 277-297.

Iceland's Minister for Foreign Affairs. Committee for the Development of a National Security Policy for Iceland. Reykjavik, Iceland: 2014.

http://eeas.europa.eu/archives/delegations/iceland/documents/press_corner/20140 324_en.pdf.

Iceland's Minister for Foreign Affairs. Foreign Minister's report to Althingi, the Parliament of Iceland. Reykjavik, Iceland: March 17, 2016. https://www.mfa.is/media/gunnar-bragi/FM-Report-to-Parliament-2016_ENsummary.pdf. 
Iceland's Parliament. A Parliamentary Resolution on Iceland's Arctic Policy. Reykjavik, Iceland: March 2011. https://www.mfa.is/media/nordurlandaskrifstofa/AParliamentary-Resolution-on-ICE-Arctic-Policy-approved-by-Althingi.pdf.

India's Ministry of External Affairs. India and the Arctic. New Delhi, India: June 10, 2013. http://mea.gov.in/in-focus-article.htm?21812/India+and+the+Arctic.

International Institute for Strategic Studies (IISS). China's strategic Arctic interests. London: International Institute for Strategic Studies, 2014. Accessed July 2, 2017. http://www.iiss.org/en/publications/strategic\%20comments/sections/2014a6f5/china--39-s-strategic-arctic-interests-05d5.

International Institute for Strategic Studies. Top 15 Defense Budgets in 2016. London: International Institute for Strategic Studies, 2017. Accessed February 1, 2018. https://www.iiss.org//media//images/publications/the\%20military\%20balance/milbal\%202017/final\%2 0free\%20graphics/mb2017-top-15-defence-budgets.jpg?la=en.

"Ilulissat Declaration." Signed May 28, 2008. Arctic Ocean Conference http://www.oceanlaw.org/downloads/arctic/Ilulissat_Declaration.pdf.

James, Carolyn C., and Patrick James. "Canada, the United States and Arctic Sovereignty: Architecture Without Building?." American Review of Canadian Studies 44, no. 2 (2014):187-204.

Japan's Cabinet. Basic Plan on Ocean Policy. Tokyo, Japan: April 2013. https://tethys.pnnl.gov/sites/default/files/publications/Japan-Ocean-Policy2013.pdf.

Japan's Headquarters for Ocean Policy. Japan's Arctic Policy. Tokyo, Japan: October 16, 2015. http://ams.hi.is/wp-content/uploads/2015/10/JAPANS-ARCTICPOLICY.pdf.

Jervis, Robert. “Cooperation Under the Security Dilemma.” World Politics 30, no. 2 (1978): 167-214.

Jervis, Robert. Perception and Misperception in International Politics. Princeton: Princeton University Press, 1976.

Joenniemi, Pertti, and Alexander Sergunin. "Russian Subnational Actors: Paradiplomacies in the European and Russian Arctic." In Future Security of the Global Arctic: State Policy, Economic Security and Climate, edited by Lassi Heininen, 55-76. London: Palgrave Macmillan, 2017. 
Johnson, Keith, and Standish Reid. "Putin and Xi are Dreaming of a Polar Silk Road." Foreign Policy, March 8, 2018. Accessed March 15, 2018. http://foreignpolicy.com/2018/03/08/putin-and-xi-are-dreaming-of-a-polar-silkroad-arctic-northern-sea-route-yamal/.

Johnston, Douglas M. “The Northwest Passage Revisited." Ocean Development and International Law 33, no. 2 (2002): 145-164.

Kaczynski, Vlad M. "US-Russian Bering Sea Marine Border Dispute: Conflict over Strategic Assets, Fisheries and Energy Resources.” Russian Analytical Digest. 20 (2007): 2-4.

Kennan, George F. Realities of American Foreign Policy. Princeton: Princeton University Press, 1954.

Kennan, George F. Memoirs, 1950-1963. New York: Pantheon Books, 1972.

Keohane, Robert O. After Hegemony: Cooperation and Discord in the World Political Economy. Princeton: Princeton University Press, 2005.

Keohane, Robert O. “Twenty Years of Institutional Liberalism.” International Relations 26, no. 2 (2012): 125-138.

Keohane, Robert O., and Joseph Nye. Power and Interdependence. Boston: Longman, 2012.

Keohane, Robert O., and Lisa L. Martin. "The Promise of Institutionalist Theory.” International Security 20, no. 1 (1995): 39-51.

Kinsella, David, Bruce Russett, and Harvey Starr. World Politics: The Menu for Choice. Boston: Wadsworth, 2013.

Konyshev, Valery, and Aleksandr Sergunin. "Is Russia a Revisionist Military Power in the Arctic." Defense and Security Analysis 30, no. 4 (2014): 323-335.

Konyshev, Valery, and Aleksandr Sergunin. "The Arctic at the Crossroads of Geopolitical Interests.” Russian Politics and Law 50, no. 2 (2012): 34-54.

Korea Inter-Ministerial. Arctic Policy of the Republic of Korea. (Report) Seoul, Korea: Maritime Institute, 2013. http://library.arcticportal.org/1902/1/Arctic_Policy_of_the_Republic_of_Korea.p dfhttp://library.arcticportal.org/1902/1/Arctic_Policy_of_the_Republic_of_Korea. pdf Accessed on August 3, 2017. 
Koremenos, Barbara, Charles Lipson, and Duncan, Snidal. "The Rational Design of International Institutions." International Organizations 55, no. 4 (2001): 761-799.

Krasner, Stephen D. Defending the National Interests: Raw Materials Investments and U.S. Foreign Policy. Princeton: Princeton University Press, 1979.

Krasner, Stephen D. International Regimes. Ithaca, NY: Cornell University Press, 1983.

Krickovic, Andrej. "When Interdependence Produces Conflict: EU-Russia Energy Relations as a Security Dilemma." Contemporary Security Policy 36, no. 1 (2015): 3-26.

Krieger, Joel. "Balance of Power." in The Oxford Companion to International Relations. Oxford: Oxford University Press, 2014.

Krieger, Joel. "Constructivism." in The Oxford Companion to International Relations. Oxford: Oxford University Press, 2014.

Kupchan, Charles A., Clifford A. and Kupchan. "Concerts, Collective Security, and the Future of Europe.” International Security 16, no. 1 (1991): 114-161.

Lackenbauer, Whitney, and Rob Huebert. "Premier Partners: Canada, the United States and Arctic Security." Canadian Foreign Policy Journal 20, no. 3 (2014): 320333.

Lagrone, Sam; and Dave Majumdar. "Planning for Joint U.S. and Russia Naval Exercise on Hold Pending Outcome in Crimea." USNI News, March 4, 2014. Accessed March 20, 2017. https://news.usni.org/2014/03/04/planning-joint-u-s-russianaval-exercise-hold-pending-outcome-crimea.

Lake, David A. "Rightful Rules: Authority, Order, and the Foundations of Global Governance." International Studies Quarterly 54, no. 3 (2010): 587-613.

Lamy, Steven L. "The U.S. Arctic Policy Agenda: The State Trumps Other Interests." In Future Security of the Global Arctic: State Policy, Economic Security and Climate, edited by Lassi Heininen, 77-98. London: Palgrave Macmillan, 2017.

Laruelle, Marlene. "Resource, state reassertion and international recognition: locating the drivers of Russia's Arctic policy." The Polar Journal 4, no. 2 (2014): 253-270.

Legro, Jeffrey W., and Andrew Moravcsik. "Is Anybody Still a Realist?.” International Security 24, no. 2 (1999) 5-55.

Lipson, Charles. "International Cooperation in Economic and Security Affairs." World Politics 37, no. 1 (1984): 1-23. 
Luszczak, Michael. "Military Cooperation and Enhanced Arctic Security in the Context of Climate Change and Growing Global Interest in the Arctic." In Future Security of the Global Arctic: State Policy, Economic Security and Climate, edited by Lassi Heininen, 1-11. London: Palgrave Macmillan, 2017.

Mazneva, Elena, Stephen Bierman, and Javier Blas. "China deepens oil ties with Russia in \$9-billion Rosneft deal.” World Oil, September 11, 2017. Accessed January 18, 2018. http://www.worldoil.com/news/2017/9/11/china-deepens-oil-ties-withrussia-in-9-billion-rosneft-deal.

Mearsheimer, John J. “A Realist Reply.” International Security 20, no 1 (1995): 82-93.

Mearsheimer, John J. “The False Promise of International Institutions.” International Security 19, no 3 (1994/5): 5-49.

Mearsheimer, John J. "Structural Realism," in Tim Dunne, Milja Kurki, and Steve Smith, eds., International Relations Theories: Discipline and Diversity, 3rd Edition (Oxford: Oxford University Press, 2013), pp. 77-93.

Mearsheimer, John J. The Tragedy of Great Power Politics. New York: W.W. Norton \& Company, 2014.

Moe, Arild, Daniel Fjaertoft, and Indra Overland. "Space and timing: why was the Barents Sea delimitation dispute resolved in 2010?." Polar Geography 34, no 3 (2011): 145-162.

Moe, Ola Borten. "Norwegian Petroleum Policy-the Arctic." Speech, Washington, DC, November 9, 2012. https://www.brookings.edu/events/norways-oil-and-gaspolicy-and-the-arctic/.

Moravcsik, Andrew. "Taking Preferences Seriously: A Liberal Theory of International Politics.” International Organization 51, no 4 (1997): 513-553.

Murray, Robert W. "Arctic Politics in the Emerging Multipolar System: Challenges and Consequences." The Polar Journal 1, no 2 (2012): 7-20.

NOAA. "NOAA GFDL Climate Research Highlights Image Gallery.” NOAA Geophysical Fluid Dynamics Laboratory. Accessed December 26, 2017. https://www.gfdl.noaa.gov/the-shrinking-arctic-ice-cap-ar4/.

Noi, Sui Goh. "China's polar ambitions cause anxiety.” The Strait Times, February 20, 2018. Accessed February 21, 2018. http://www.straitstimes.com/asia/eastasia/chinas-polar-ambitions-cause-anxiety. 
Nordic Council. "The History of the Nordic Council." Nordic Council. Accessed June 7, 2017. http://www.norden.org/en/nordic-council/bag-om-nordisk-raad/the-nordiccouncil/the-history-of-the-nordic-council/1953-1971.

North Atlantic Treaty Organization (NATO). Active Engagement, Modern Defense: Strategic Concept for the Defense and Security of the Members of the North Atlantic Treaty Organization. Lisbon, Portugal: November 20, 2010. https://www.nato.int/cps/ua/natohq/official_texts_68580.htm.

North Atlantic Treaty Organization. "Defense Expenditure of NATO Countries (20092016).” North Atlantic Treaty Organization. Accessed February 1, 2018. https://www.nato.int/nato_static_fl2014/assets/pdf/pdf_2017_03/20170313_1703 13-pr2017-045.pdf.

North Atlantic Treaty Organization. Wales Summit Declaration. Newport, Wales: September 5, 2014. http://www.nato.int/cps/en/natohq/official_texts_112964.htm.

Northern Dimension. "Exploring the Northern Dimension.” Accessed July 2, 2017. Northern Dimension. http://www.northerndimension.info/northern-dimension.

Norwegian Ministry of Foreign Affairs (NMFA). High North Strategy. Oslo, Norway. December 1, 2006.

Norwegian Ministry of Foreign Affairs. New Building Blocks in the North: The next step in the Government's High North Strategy. Oslo/Tromso, Norway: March 12, 2009.

https://www.regjeringen.no/globalassets/upload/ud/vedlegg/nordomradene/new_b uilding_blocks_in_the_north.pdf.

Norwegian Ministry of Foreign Affairs. Norway's Arctic Strategy: Between Geopolitics and Social Development. Oslo, Norway: November 2014. https://www.regjeringen.no/contentassets/fad46f0404e14b2a9b551ca7359c1000/a rctic-strategy.pdf.

O’Connor Tom, “Russia's and China's Presidents are Winning big as they Challenge U.S. and take Power from West." Newsweek, March 20, 2018. http://www.newsweek.com/russia-china-presidents-win-big-challenging-usmilitary-rise-around-world-851801.

Office of Management and Budget. An American Budget. Washington, DC: Government Printing Office, 2018. https://www.whitehouse.gov/wpcontent/uploads/2018/02/budget-fy2019.pdf. 
People's Republic of China (PRC). China's Arctic Policy. Beijing: State Council Information Office. 2018.

http://english.gov.cn/archive/white_paper/2018/01/26/content_281476026660336. $\underline{\mathrm{htm}}$.

Powell, Richard C. "Lines of possession? The anxious constitution of polar geopolitics". Political Geography 29, no. 2 (2010): 74-77.

Pravda. "Putin increases size of Russian army." Pravda, March 29, 2017. Accessed April 1, 2017. http://www.pravdareport.com/news/russia/29-03-2017/137259-army-0/.

President of Russia. Congratulations to Xi Jinping on his re-election as Chinese President. Moscow, Russia: March 17, 2018. http://en.kremlin.ru/events/president/news/57081.

Putin, Vladimir. Meeting of the Security Council on state policy in the Arctic. Moscow, Russia: April 22, 2014. http://en.kremlin.ru/events/president/news/20845.

Putin, Vladimir. The Strategy for the Development of the Arctic Zone of the Russian Federation and Ensuring National Security for the Period up to 2020. Moscow, Russia: February 20, 2013. http://www.research.kobe-u.ac.jp/gsicspcrc/sympo/20160728/documents/Keynote/Russian\%20Arctic\%20strategy\%2020 13.pdf.

Putin, Vladimir. Edited by Gevorkyan, Nataliya; Natalya Timakova, and Andrei Kolesnikov. First Person: An Astonishingly Frank Self-Portrait by Russia's President. Translated by Catherine A. Fitzpatrick. New York: Public Affairs, 2000.

Reagan, Ronald. "Statement on United States Oceans Policy.” Speech, Washington, DC, March 10, 1983. Reagan Library. https://reaganlibrary.archives.gov/archives/speeches/1983/31083c.htm.

Republic of Korea. Arctic Policy of the Republic of Korea. Seoul, Korea: 2013. http://library.arcticportal.org/1902/1/Arctic_Policy_of_the_Republic_of_Korea.p df.

Reus-Smit, Christian. "The Constitutional Structure of International Society and the Nature of Fundamental Institutions." International Organizations 51, no. 4 (1997): 555-589.

Rosneft Information Division. "Rosneft Strengthens Cooperation with China." January 9, 2017. Accessed December 30, 2017. https://www.rosneft.com/press/releases/item/185283/. 
Ruggie, John Gerald. "Multilateralism: The Anatomy of an Institution." International Organization 46, no. 3 (1992): 561-598.

Russell, Richard. "American Diplomatic Realism: A tradition practiced and preached by George F. Kennan.” Diplomacy and Statecraft 11, no. 3 (2000): 159-182.

Russian Federation. "Military Doctrine of the Russian Federation.” (2014) Accessed June 19, 2017. https://www.offiziere.ch/wp-content/uploads-001/2015/08/Russia-s2014-Military-Doctrine.pdf

Russian Federation. The foundations of Russian Federation policy in the Arctic until 2020 and beyond. Moscow, Russia: 2009 http://www.arctissearch.com/Russian\%2BFederation\%2BPolicy\%2Bfor\%2Bthe\%2BArctic\%2Bto $\% 2 \mathrm{~B} 2020$.

Russian Federation. Russian National Security Strategy 2015. Moscow, Russia: 2015. http://www.ieee.es/Galerias/fichero/OtrasPublicaciones/Internacional/2016/Russia n-National-Security-Strategy-31Dec2015.pdf.

Russia Today. "Putin to Oliver Stone: I suggested Russia joining NATO to Clinton, he didn't mind." Russia Today, June 3, 2017. Accessed June 26, 2017. https://www.rt.com/news/390724-putin-clinton-russia-nato-stone/.

Sakhuja, Vijay. "China Breaking the Ice.” Indian Council of World Affairs. 2010. Accessed August 2, 2017. http://www.icwa.in/pdfs/ib\%20\%20dr.pdf.

Schonfeldt, Kristina. The Arctic in International Law and Policy. Oxford: Hart Publishing, 2017.

Seattle Times News Service. "Medvedev: Arctic resources are key to Russia's future." Seattle Times, September 18, 2008. Accessed April 20, 2017. http://www.seattletimes.com/nation-world/medvedev-arctic-resources-are-key-torussias-future/.

Sharp, Todd. "The Implication of Ice Melt on Arctic Security.” Defense Studies 11, no. 2 (2011): 297-322.

Shapiro, Michael. Methods and Nations: Cultural Governance and the Indigenous Subject. London and New York: Routledge, 2004.

Shirreff, Richard. War with Russia: An Urgent Warning from Senior Military Command. New York and London: Quercus, 2016. 
Shlapak, David A. and Michael W. Johnson. Reinforcing Deterrence on NATO's Eastern Flank: Wargaming the Defense of the Baltics. RR-1253-A. Santa Monica, CA: RAND Corp, 2016. https://www.rand.org/pubs/research_reports/RR1253.html.

Snyder, Jack “One World, Rival Theories.” Foreign Policy 145 (2004): 55-62.

Staun, Jorgen. "Russia's strategy in the Arctic: cooperation, not confrontation." Polar Record 53, no. 270 (2017): 314-332.

Stokke, Olav S. "Regime Interplay in Arctic shipping governance: explaining regional niche selection.” International Environmental Agreements 13, no. 3 (2013): 6585.

Sweden's Ministry for Foreign Affairs. Sweden's Strategy for the Arctic Region. Stockholm, Sweden: 2011. https://openaid.se/wpcontent/uploads/2014/04/Swedens-Strategy-for-the-Arctic-Region.pdf.

Tang, Shiping. “The Security Dilemma: A Conceptual Analysis.” Security Studies 18, no. 3 (2009): 587-623.

“Task Force on Arctic Marine Cooperation.” Signed April 2015. https://oaarchive.arcticcouncil.org/bitstream/handle/11374/1923/2017-04-30-Edocs-4079-v3-TFAMCreport-to-ministers-with-cover-and-colophon.pdf?sequence $=1 \&$ is Allowed=y.

Taylor, Adam. "China treats its foreign aid like a state secret. New research aims to reveal it." Washington Post, October 11, 2017. Accessed October 13, 2017. https://www.washingtonpost.com/news/worldviews/wp/2017/10/11/china-treatsits-foreign-aid-like-a-state-secret-new-research-aims-to-revealit/?utm_term=.df $1 \mathrm{fdbd} 421 \mathrm{ca}$.

Tillerson, Rex W. "The U.S. and Europe: Strengthening Western Alliances.” Speech, Washington, DC, November 28, 2017. U.S. Department of State. https://www.state.gov/secretary/remarks/2017/11/276002.htm.

Titley, David W., and Courtney C. St. John. "Arctic Security Considerations and the U.S. Navy's Roadmap for the Arctic." Naval War College Review 63, no. 2 (2010): 3548.

Tharoor, Ishaan. "The Arctic is Russia's Mecca, says top Moscow Official." Washington Post, April 20, 2015. Accessed April 20, 2017. https://www.washingtonpost.com/news/worldviews/wp/2015/04/20/the-arctic-isrussias-mecca-says-top-moscow-official/?utm_term=.9f47beea7f8d.

Thompson, Alexander. "Coercion Through IOs: The Security Council and the logic of Information Transmissions." International Organization 60, no. 1 (2006): 1-34. 
“Tromso Declaration.” Signed April 2009. https://oaarchive.arcticcouncil.org/bitstream/handle/11374/91/06_tromso_declaration_2009_signed\%20 $\% 281 \% 29$.pdf? sequence $=1 \&$ is Allowed $=y$.

Tselichtchev, Ivan. "Chinese in the Russian Far East: A geopolitical Time Bomb?." South China Morning Post, July 8, 2017. Accessed July 10, 2017. http://www.scmp.com/week-asia/geopolitics/article/2100228/chinese-russian-fareast-geopolitical-time-bomb.

Turak, Natasha. "Trump to agree to new Russia sanctions but impact will be minimal, analysts predict." CNBC, January 29, 2018. Accessed January 30, 2018. https://www.cnbc.com/2018/01/29/new-us-russia-sanctions-trump-to-comply-butimpact-will-be-minimal.html.

Union of Soviet Socialist Republics' Minister of Merchant Marine. Regulations for Navigation on the Seaways of the Northern Sea Route. Moscow, U.S.S.R: September 14, 1990. http://www.arcticlio.com/docs/nsr/legislation/Rules_of_navigation_on_the_seaways_of_the_North ern_Sea_Route.pdf.

United Nations Environmental Protection. Agreement on Conservation of Polar Bears. Oslo, Norway: November 15, 1973. http://sedac.ciesin.org/entri/texts/polar.bears.1973.html.

United States Embassy of Norway. U.S. Special Representative to the Arctic, Admiral Papp, visits Norway, 2015. https://no.usembassy.gov/u-s-special-representativearctic-admiral-papp-visits-norway/.

U.S. Library of Congress. Congressional Research Service. The Chinese Military: Overview and Issues for Congress, by Ian E. Rinehart. RL44196. 2016.

United States Navy. The United States Navy Arctic Roadmap for 2014 to 2030. Washington: Chief of Naval Operations. 2014. http://www.navy.mil/navydata/documents/USN_artic_roadmap.pdf.

Walt, Stephen. "International Relations: One World, Many Theories.” Foreign Policy 110 (1998): 29-46.

Walt, Stephen M. The Origins of Alliances. Ithaca: Cornell University Press, 1987.

Waltz, Kenneth N. Man, the State and War: A Theoretical Analysis. New York: Columbia University Press, 1959. 
Waltz, Kenneth N. "The Emerging Structure of International Politics." International Security 18, no. 2 (1993): 44-79.

Waltz, Kenneth N. "The Origins of War in Neorealist Theory." The Journal of Interdisciplinary History 18, no. 4 (1988): 615-628.

Waltz, Kenneth N. Theory of International Politics. Boston: McGraw-Hill, 1979.

Wang, Yong. "Norway's Arctic Strategy: Profitability and Environmental Responsibility." American Security Project December 4, 2012. https://www.americansecurityproject.org/norways-arctic-strategy-profitabilityand-environmental-responsibility/.

Wegge, Njord. "The political order in the Arctic: power structures, regimes and influence.” Polar Record 47, no. 2 (2011): 165-176.

Wendt, Alexander. "Anarchy is what States Make of it: The Social Construction of Power Politics.” International Organization 46, no. 2 (1992): 391-425.

Wendt, Alexander. Social Theory of International Politics. Cambridge: Cambridge University Press, 1999.

Westcott, Ben. "China says relations with Russia at best level in history." CNN, April 6, 2018. Accessed December 30, 2017. https://www.cnn.com/2018/04/06/asia/russia-china-relations-us-intl/index.html.

Wezeman, Siemon T. "China, Russia and the Shifting landscape of arms sales." SIPRI, July 5, 2017. Accessed December 30, 2017. https://www.sipri.org/commentary/topical-backgrounder/2017/china-russia-andshifting-landscape-arms-sales.

White House. A New National Security Strategy for a New Era. Washington, DC: December 18, 2017. https://www.whitehouse.gov/articles/new-national-securitystrategy-new-era/.

White House. National Security Presidential Directive/NSC-26. Washington, DC: June 9, 1994.

White House. National Security Presidential Directive/NSPD-66 - Homeland Security Presidential Directive/HSPD-25. Washington, DC: 2009.

White House. National Security Strategy. Washington, DC: 2010. http://nssarchive.us/NSSR/2010.pdf. 
White House. National Strategy for the Arctic Region. 2013. https://obamawhitehouse.archives.gov/sites/default/files/docs/nat_arctic_strategy. pdf

White House. President Donald J. Trump's State of the Union Address. January 30, 2018. https://www.whitehouse.gov/briefings-statements/president-donald-j-trumps-state-unionaddress/.

Williams, Lisa. "Canada, the Arctic, and Post-National Identity in the Circumpolar World." The Northern Review. 33 (2011): 113-131.

Wintour, Patrick. "Troubled waters: Norway keeps watch on Russia's Arctic maneuvers." The Guardian, March 13, 2017. Accessed April 20, 2017. https://www.theguardian.com/world/2017/mar/13/troubled-waters-norway-keepswatch-on-russias-arctic-manoeuvres.

Wright, David Curtis. "China's Growing Interests in the Arctic." Journal of Military and Strategic Studies. 15, no. 2 (2013): 50-71.

Naval War College China Maritime Studies Institute. The Dragon Eyes the Top of the World: Arctic Policy Debate and Discussion in China by David Curtis Wright,. Periodical. August 2011.

World Bank. "Population, total." 2016. https://data.worldbank.org/indicator/SP.POP.TOTL.

Wu, DD. "China and Russia sign military Cooperation Roadmap." The Diplomat, June 30, 2017. Accessed July 6, 2017. https://thediplomat.com/2017/06/china-andrussia-sign-military-cooperation-roadmap/.

Xinhua. "Xi congratulates Putin on his election as Russian president." China Daily, March 19, 2018. Accessed March 20, 2018. http://www.chinadaily.com.cn/a/201803/19/WS5aaf06daa3106e7dcc1425bf.html.

Young, Oran R. "The Future of the Arctic: cauldron of conflict or zone of peace." International Affairs 87, no. 1 (2011): 185-193.

Young, Oran R., and Gail Osherenko. Polar Politics: Creating International Environmental Regimes. Ithaca, NY: Cornell University Press, 1993. 